\title{
Mineral-Inspired Materials: Synthetic Phosphate Analogues for Battery Applications
}

\author{
Olga Yakubovich ${ }^{1, *(\mathbb{D},}$, Nellie Khasanova ${ }^{2}$ and Evgeny Antipov ${ }^{2,3}$ \\ 1 Department of Crystallography, Geological Faculty, M.V. Lomonosov Moscow State University, \\ Leninskie Gory 1, 119991 Moscow, Russia \\ 2 Chemical Faculty, M.V. Lomonosov Moscow State University, Leninskie Gory 1, 119991 Moscow, Russia; \\ nelkh77@gmail.com (N.K.); evgeny.antipov@gmail.com (E.A.) \\ 3 Skolkovo Institute of Science and Technology, 3 Nobel Street, 143025 Moscow, Russia \\ * Correspondence: yakubol@geol.msu.ru; Tel.: +7-903-975-91-06
}

Received: 28 April 2020; Accepted: 5 June 2020; Published: 7 June 2020

\begin{abstract}
For successful development of novel rechargeable batteries, considerable efforts should be devoted to identifying suitable cathode materials that will ensure a proper level of energy output, structural stability, and affordable cost. Among various compounds explored as electrode materials, structural analogues of minerals-natural stable inorganic solids-occupy a prominent place. The largest number of varieties of phosphate minerals occurs in rare metal granite pegmatites, and many of which contain transition metals as essential components. Transition metal phosphates are promising candidates for exploration as cathode materials due to a perfect combination of easily scalable synthesis, moderate-to-high voltage operation, thermal/chemical stability, and environmental safety. However, impurities usually presented in natural objects, and often inappropriate sample morphologies, do not permit the use of minerals as battery electrode materials. Nevertheless, the minerals of different classes, especially phosphates, are considered as prototypes for developing novel materials for battery applications. The crystal chemical peculiarities of the phosphate representatives that are most relevant in this aspect and the electrochemical characteristics of their synthetic analogues are discussed here.
\end{abstract}

Keywords: phosphates; minerals; battery materials; cathode; synthetic analogous; crystal structure; electrochemistry; homeotypes; pegmatites; energy storage

\section{Introduction}

"They created a rechargeable world": the 2019 Nobel Prize in Chemistry was awarded to John B. Goodenough, M. Stanley Whittingham, and Akira Yoshino for their contribution to the development of lithium-ion batteries, which revolutionized our daily life and laid the foundation of a wireless fossil fuel-free society [1].

Ever-growing demands for energy and depleting of fossil fuels require utilizing renewable energy resources (solar, wind, geothermal). For accumulating the energy from these intermittent sources, we need highly efficient energy conversion and storage systems. Rechargeable batteries are the most efficient energy storage technology for a wide range of devices from portable electronics to electric vehicles and grids [2]. Meeting the future needs of our society requires a significant improvement of existing Li-ion technology and development of alternative Na- and $\mathrm{K}$-ion batteries, and the main research task is to find suitable materials for electrodes. The discovered ability of synthetic triphylite $\mathrm{LiFePO}_{4}$ to reversibly de/intercalate lithium ions [3] has brought great attention to transition metal phosphates as electrode materials for Li-ion batteries.

Phosphates are the most widespread minerals in the Earth's crust after silicates and oxides. Their remarkable structural diversity allows for a large range of technological applications such 
as magnetic and nonlinear optical materials, catalysts, adsorbents, molecular sieves, phosphors, and biomaterials, to name but a few [4]. The advance of battery technologies promotes more sustainable and environmentally friendly energy production, storage, and consumption. Transition metal phosphates are attractive here due to their enhanced thermodynamic and kinetic stability compared to oxides, higher operating potentials owing to the inductive effect of the phosphate group for the same cation redox couples, and the environmental friendliness of their robust crystal structures.

However, the mineral phases may not be suitable for research due to the unstable impurities typically present in natural samples. At the same time, their crystal structures, often with such promising features as low dimensionality, lack of a center of symmetry, ion diffusion channels may serve as excellent reference points for the development of new materials. The use of information on chemical compositions, structural features, and conditions of mineral formation and alteration in the Earth's crust is essential for understanding and adequate interpretation of the properties of their synthetic analogues. Thus, crystal chemical study of transition metal phosphates with alkali atoms makes it possible to determine the miscibility limits of solid solutions and to find ways to control cation ordering, defect concentration, and ion oxidation, which are important for creating electrochemically active materials. Moreover, phosphate-based materials provide ease of synthesis along with reliable electrochemical characteristics.

In this review, we will demonstrate the definite attractiveness of minerals, mainly phosphates, as a source of inspiration for researchers working in the field of battery materials.

\section{Background Information}

Modern technologies require a tremendous amount of energy, and the problem of energy storage is now key for the world energy supply. A secondary (or rechargeable) battery is an electrochemical energy storage device, which converts chemical energy into electrical energy and vice versa in a repeated way. Among the present batteries, Li-ion technology is the best due to high delivered energy density, long cycle life, rate capability, and energy efficiency. The Li-ion battery (LIB) comprises one or more sequential or parallel single electrochemical cells consisting of two electrodes (anode and cathode) and a non-aqueous electrolyte, which supports the transport of charge carriers between the separated electrodes. The process of energy storage is carried out through the reversible de/intercalation of alkali metal ions into the electrode materials. During charge, the electrons are pumped "uphill", thermodynamically speaking, from a positive (cathode) to a negative (anode) electrode through an external circuit; ions also flow toward the anode but through the electrolyte to complete the circuit and keep the reaction running (Figure 1). The opposite process occurs during discharge: the favorable free energy of the redox pair allows the reaction to proceed "downhill", thereby providing energy to the device that receives power from the battery.

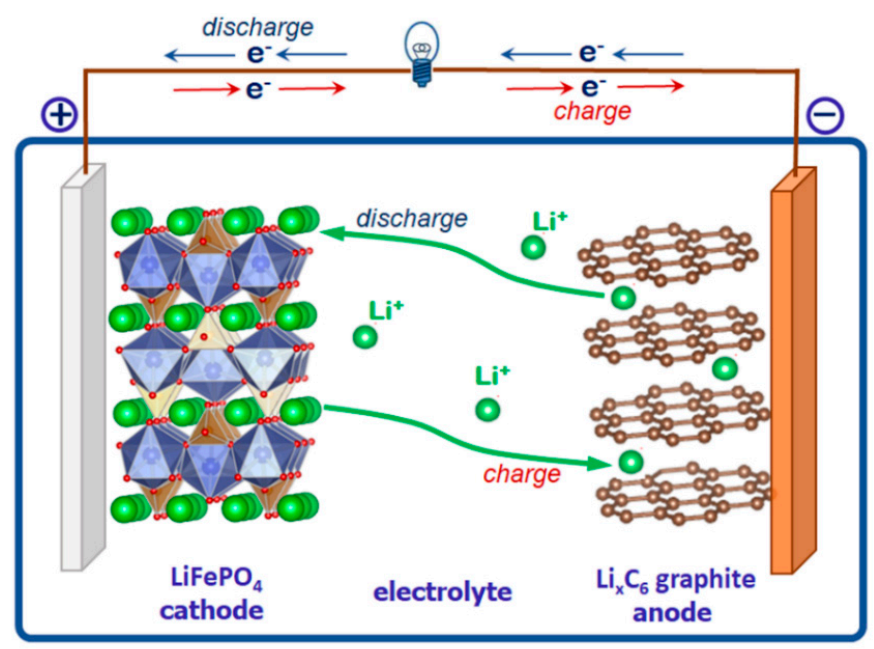

Figure 1. Schematics of Li-ion battery. 
Battery performance is evaluated by power and energy density parameters. Power refers to the amount of energy that can be instantaneously released by a battery, while the energy density of a battery is defined as its specific capacity (the amount of charge passed between the cathode and the anode per unit mass) multiplied by the potential difference between these electrodes. These parameters depend on the choice of active electrode materials (particularly the cathode material), which must meet severe chemical and electrochemical requirements. They must demonstrate a high specific capacity, fast reversible de/intercalation of alkali ions, and sufficient electrical conductivity. In addition, they must undergo reversible structural changes with minimal volume changes upon cycling. Of particular note is the requirement for a high specific capacity defined by the formula:

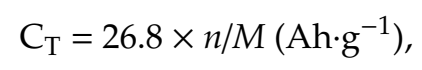

where $n$ is the number of electrons (or alkali metal ions) involved in the reaction, $M$ is the molar weight of the compound, and 26.8 is the Faraday constant, normalized to Ah units. The smaller the molar mass of the compound and the greater the number of alkali metal ions involved in the reversible process, the higher the specific capacity obtained. This limits the choice of electrochemically active metal by $3 \mathrm{~d}$ and $4 \mathrm{~d}$ transition metals $(\mathrm{Ti}, \mathrm{V}, \mathrm{Cr}, \mathrm{Mn}, \mathrm{Fe}, \mathrm{Co}, \mathrm{Ni}, \mathrm{Cu}, \mathrm{Nb}, \mathrm{Mo}$ ), which are capable of demonstrating multiple oxidation states that can be easily converted from one to the other. The working potential of the electrode material is determined by the electrochemically active transition metal and its coordination environment [5].

First-generation cathode materials for LIBs based on layered $\mathrm{LiMO}_{2}$ oxides $(\mathrm{M}=\mathrm{Mn}, \mathrm{Co}, \mathrm{Ni})$ with a NaCl-derivative structure and a spinel $\mathrm{LiMn}_{2} \mathrm{O}_{4}$ are still widely used in different portable devices [6]. Despite the high specific capacity (up to $180-200 \mathrm{mAh} \cdot \mathrm{g}^{-1}$ ) delivered by the mixed oxides $\mathrm{LiNi}_{\mathrm{x}} \mathrm{Mn}_{\mathrm{x}} \mathrm{Co}_{1-2 \mathrm{x}} \mathrm{O}_{2}$ with a layered structure, application of these cathodes in large-scale devices is limited due to their thermal instability and due to their high cost [7].

The development and commercial success of $\mathrm{LiFePO}_{4}$-based cathode materials has drawn attention to compounds with various anion groups, $\left(\mathrm{XO}_{m}\right)^{n-}$ [3]. Despite the smaller theoretical gravimetric capacity owing to the presence of heavy oxoanion groups in the composition, these materials provide a number of advantages, which make them a good alternative to oxide materials for use in large-scale applications. Thus, their robust framework supports long-term structural stability and contributes to the superior cycle life and high safety. Due to the inductive effect of the $\left(\mathrm{XO}_{m}\right)^{n-}$ group, these materials exhibit higher operating potentials compared to that in oxides, resulting in enhanced specific energy density [5]. Compounds with complex anions adopt a large number of atomic arrangements, providing a rich variety of crystal structures. In the last two decades, compounds with different tetrahedral oxoanion groups, such as silicates, phosphates, sulfates, pyrophosphates, and their fluorinated compounds, have been widely investigated [8,9].

For most of the LIB cathode materials used, the potential for further enhancement of their performance characteristics has already been exhausted, so the search for new cathode materials with high specific energy is an important task from both fundamental and practical points of view. For large power supplies, when the price per kilowatt-hour becomes an important parameter, the low relative abundance of the constituent elements should be taken into account [10]. It imposes restriction on the use of rare metals, lithium, as well as cobalt, which functions as a redox center within the battery. For this reason, the development of alternative metal-ion technologies based on $\mathrm{Na}-, \mathrm{K}-, \mathrm{Mn}-$, and Fe-containing compounds may considerably reduce the cost and environmental impact.

$\mathrm{Na}$ and $\mathrm{K}$ are widely distributed in nature; in comparison to the occurrence of $\mathrm{Li}(20 \mathrm{ppm})$ in the Earth's crust, the abundance of $\mathrm{Na}(23,000 \mathrm{ppm})$ and $\mathrm{K}(17,000 \mathrm{ppm})$ seems to be limitless, and they occupy, respectively, seventh and eighth places in the elemental content of the crust [2]. Considering the quite similar chemistry of $\mathrm{Li}, \mathrm{Na}$, and $\mathrm{K}$ alkali metals, the alternative metal-ion batteries can take advantage of the working principles and manufacturing technologies of mature LIB. Sodium $\left(\mathrm{Na}^{+}\right)$ and potassium $\left(\mathrm{K}^{+}\right)$ions are heavier and have larger ionic radii than lithium ions $\left(\mathrm{Li}^{+}\right)$and, therefore, Na-ion batteries (NIBs) and K-ion batteries (KIBs) are not expected to compete with LIBs for volumetric 
and gravimetric energy density, but it is anticipated that their abundant resources will be put to use to ensure price competitiveness and to complement LIBs in large-scale applications [2,11]. It should also be mentioned that $\mathrm{Na}$ and $\mathrm{K}$ ions may exhibit higher diffusion rates in crystal frameworks compared to Li-ions; thus, leading to the higher specific power of these types of batteries. While the KIB finds itself at an early stage of development, the NIB technology is already approaching a satisfactory level for commercialization considering the energy density and cycle life: today NIBs are considered as a low-cost solution to replace toxic lead-acid batteries.

KIBs have recently aroused great interest because of the certain advantages they can provide. Among these three alkali metals, $\mathrm{K}^{+}$has the smallest Stoke's radius of solvated ions, resulting in the highest ion mobility and ion conductivity in liquid electrolytes. More importantly, in non-aqueous electrolytes, $\mathrm{K}$ demonstrates a lower standard redox potential than $\mathrm{Na}$ and even $\mathrm{Li}$, and therefore potentially KIBs can offer higher operating voltage, providing higher energy density [2].

For the successful development of new technologies, considerable efforts should be devoted to identifying suitable cathode materials that will ensure a proper level of energy output, structural stability, and affordable cost. In the search for electrochemically active transition metals, iron and manganese prevail over other metals. Iron is one of the rock-forming elements; it is extremely widely distributed in the Earth's crust (56,300 ppm) and is the cheapest non-toxic transition metal. Manganese is another rock-forming element that is widespread: an enormous amount of manganese nodules have been discovered recently on the seabed. These metals form various compounds which demonstrate electrochemical activity with appropriate operating potentials corresponding to $\mathrm{Fe}^{2+} / \mathrm{Fe}^{3+}$ and $\mathrm{Mn}^{2+} / \mathrm{Mn}^{3+}$ redox couples; moreover, Mn-based compounds can offer an ideal combination of high-voltage performance, low cost, and environmental safety.

Among various compounds with oxoanion groups explored as electrode materials, structural analogues of minerals occupy a prominent place. This suggests that mineral-like compounds, primarily phosphates and silicates, might be prototypes of novel materials with attractive electrochemical properties. Phosphates are evident leaders among complex anions, having a perfect combination of easily scalable synthesis, moderate-to-high voltage operation, and thermal/chemical and operational stability.

\section{Phosphate Minerals in Pegmatites}

Granite pegmatites present a source of raw materials for glass and ceramics, silicon for microprocessors, and industrial metals, for example, $\mathrm{Li}, \mathrm{Cs}, \mathrm{Be}, \mathrm{Nb}, \mathrm{Ta}, \mathrm{Sn}, \mathrm{REEs}$, and U. This type of rock is unique in having a variety of economically significant minerals and colored gemstones in such a concentrated form [12]. Although the largest amount of phosphorus is concentrated in apatite deposits, the greatest number of varieties of phosphate minerals occurs in rare metal granite pegmatites. According to Moore [13], about 190 phosphates are associated with granite pegmatites and at least 40 of them are primary phases formed directly from pegmatite fluid. Analysis of the chemical formulae of more than 200 phosphate minerals showed that the most common cations in phosphates are $\mathrm{Fe}^{2+}$ and $\mathrm{Fe}^{3+}$ (95 compounds), $\mathrm{Al}^{3+}(60), \mathrm{Ca}^{2+}(56), \mathrm{Mn}^{2+}$, and $\mathrm{Mn}^{3+}$ (45) [14]. A novel classification of granitic pegmatites, including phosphate minerals, was presented in [15].

The high-temperature primary minerals that crystallize in the core of pegmatite (triplite-zwieselite, amblygonite-montebrasite, triphylite-lithiophilite series, etc.) have the more complicated three-dimensional frameworks formed by octahedra or/and five vertex polyhedra [16]. As shown in [17], $75 \%$ of the high-temperature phosphates possess densely packed or "denser-than-densely-packed" structures. Their frameworks incorporate "clusters" of octahedra sharing edges and faces, while $\mathrm{PO}_{4}$ tetrahedra, in these structures, have edge contacts with metal-centered polyhedra. Giant crystals, over one meter in dimension (graftonite, apatite, arrojadite, and triphylite) are known for the primary phosphates [18].

Greatly "polymerized" associations of octahedra sharing edges and vertices are the basis of crystal structures of early metasomatic phosphates that crystallize at the boundary of the pegmatite core 
and an intermediate zone. They form along the initial metasomatic replacements as a result of the alteration of the earlier phosphates under the action of the later fluid and usually they are presented by smaller crystals [19]. A distinctive typomorphic feature of these phosphate minerals is the presence of mixed valence transition metals, resulting in the dark brown-black or green-black colors due to a $M^{2+} \leftrightarrow M^{3+}$ charge transfer. Their 3D frameworks built by amphoteric oxocomplexes contain hole defects (arrojadite, lipscombite, wyllieite), or their constructions present one-dimensional (1D) tapes and two-dimensional (2D) layers (alluaudite, kryzhanovskite) of edge-sharing octahedra.

Depending on the conditions of crystal genesis, amphoteric complexes can form the cationic part of the crystal structure or act as anions together with acid tetrahedral groups. In other words, in combination with, for instance, acid $\left(\mathrm{PO}_{4}\right)^{3-}$ oxocomplexes, amphoteric metal complexes can form mixed anionic networks similar to organic polyanions [20]. The amphotericity of oxocomplexes of transition metals and some others is well known in chemistry. This property turned out to be the defining geochemistry of many natural processes. In the alkaline conditions of mineral genesis (agpaitic pegmatites, hydrothermalites, etc.), the alkaline metals quantitatively dominate in the system of crystallization. Under conditions of increased alkalinity, the cationic fragment of the crystal structure is usually built by alkaline elements, while amphoteric oxocomplexes together with acid tetrahedra form its anionic part in the presence of a significant amount of more electropositive cations. These anionic constructions may be formed by octahedra and/or five vertex polyhedra around an amphoteric metal, sharing vertices with acid $\mathrm{PO}_{4}$ tetrahedra, or by chemically different tetrahedral oxocomplexes. The phosphate minerals containing significant amount of alkali cations may have zeolite-like microporous architecture [21-23].

\section{Mineral Prototypes for Battery Design}

\subsection{Phosphates of the Triphylite Li(Fe, Mn $\mathrm{PO}_{4}-$ Lithiophilite $\mathrm{Li}(\mathrm{Mn}, \mathrm{Fe}) \mathrm{PO}_{4}$ Series and Their Derivatives}

4.1.1. The Triphylite $\mathrm{Li}(\mathrm{Fe}, \mathrm{Mn}) \mathrm{PO}_{4}$-Lithiophilite $\mathrm{Li}(\mathrm{Mn}, \mathrm{Fe}) \mathrm{PO}_{4}$ Series: Occurrence, Crystal Chemistry, and Electrochemical Behavior

Phosphate of the triphylite $\mathrm{Li}(\mathrm{Fe}, \mathrm{Mn}) \mathrm{PO}_{4}$-lithiophilite $\mathrm{Li}(\mathrm{Mn}, \mathrm{Fe}) \mathrm{PO}_{4}$ series [olivine-type minerals with an ordered distribution of Li and Fe (Mn) among M1 and M2 sites surrounded by oxygen octahedra] are the most abundant among the accessory minerals in granite pegmatites. These phosphates may form crystals with sizes up to several meters. Field studies show that the minerals in the series are primary phases associated with alkali feldspar and quartz in the middle and inner parts of zoned granite pegmatites $[13,24]$. Subsequently attacked by aqueous rest liquid during consolidation of the pegmatite, members of the triphylite-lithiophilite solid solution series are subject to stepwise alteration. First, the oxidation of $\mathrm{Fe}^{2+}$ to $\mathrm{Fe}^{3+}$ together with reductions in the lithium content and the formation of the ferrisicklerite $\mathrm{Li}_{1-x}\left(\mathrm{Fe}^{3+}{ }_{x} \mathrm{Fe}^{2+}{ }_{1-x}\right) \mathrm{PO}_{4}-$ sicklerite $\mathrm{Li}_{1-x}\left(\mathrm{Mn}^{3+}{ }_{x} \mathrm{Mn}^{2+}{ }_{1-x}\right) \mathrm{PO}_{4}$ minerals, and second, $\mathrm{Mn}^{2+}$ to $\mathrm{Mn}^{3+}$ oxidation followed by complete extraction of the lithium and the formation of phosphates of the isomorphous heterosite-purpurite series $\left(\mathrm{Fe}^{3+}, \mathrm{Mn}^{3+}\right) \mathrm{PO}_{4}[25]$. The small $\mathrm{Li}^{+}$cations are quite leachable and the primary crystals easily suffer hydrothermal attack without structure collapse: the crystal structure of heterosite (purpurite) is based on the same hexagonal close packing of oxygen atoms as triphylite (lithiophilite) but with ordered vacancies in the cation positions formerly occupied by lithium [17] (Figure 2).

The first single crystal triphylite end member, $\mathrm{LiFePO}_{4}$ (crystal characteristics of synthetic analogues of minerals, studied as cathode materials, are given in Table 1 in the conclusion section), was hydrothermally synthesized and structurally characterized in 1977 [26]. Twenty years later, Goodenough's group discovered the electrochemical activity of $\mathrm{LiFePO}_{4}$ and stated this phosphate as a candidate for the cathode of rechargeable lithium batteries [3]. $\mathrm{LiFePO}_{4}$ satisfies many of the criteria for an electrode material. It reversibly de/intercalates $\mathrm{Li}$, exhibiting a flat plateau around $3.45 \mathrm{~V}$ (vs. $\mathrm{Li} / \mathrm{Li}^{+}$) because of a two-phase redox reaction mechanism with the formation of fully delithiated $\mathrm{FePO}_{4}$. This material has good gravimetric capacity $\left(170 \mathrm{mAh} \cdot \mathrm{g}^{-1}\right)$ and is stable against 
overcharge or discharge and compatible with commercially available electrolyte systems. It is also environmentally friendly and cheap. Nevertheless, there are several disadvantages associated with the moderate operating potential and, consequently, relatively low energy density (volumetric especially), large volume change during cycling $(\sim 7 \%)$, poor electronic conductivity and a two-phase mechanism of $\mathrm{Li}^{+}$ion de/intercalation.

a)

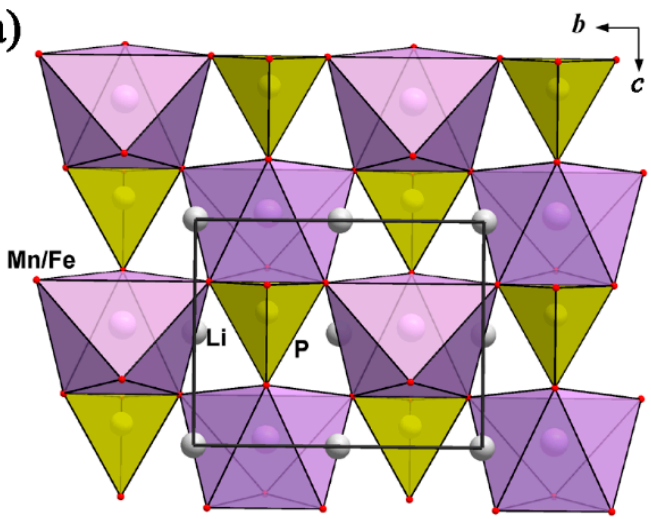

b)

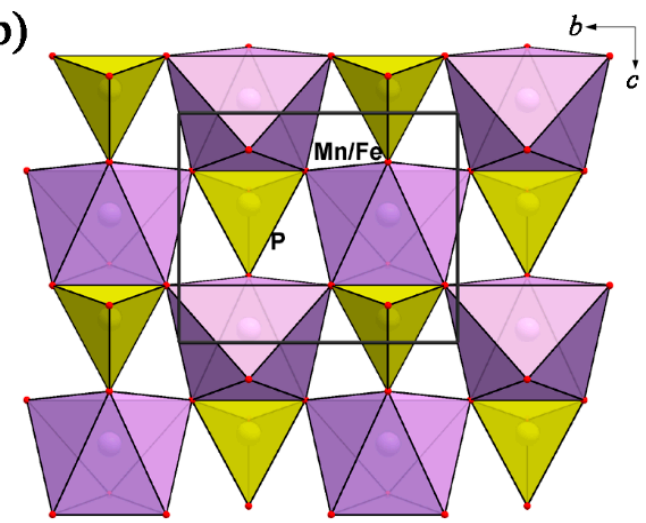

Figure 2. Layers built by $\mathrm{Mn} / \mathrm{Fe}$-centered octahedra and $\mathrm{PO}_{4}$ tetrahedra parallel to $y z$ plane in the crystal structures of lithiophilite, $\mathrm{Li}(\mathrm{Mn}, \mathrm{Fe}) \mathrm{PO}_{4}(\mathbf{a})$ and purpurite, $(\mathrm{Mn}, \mathrm{Fe}) \mathrm{PO}_{4}(\mathbf{b})$.

The electrochemical behavior of the natural triphylite $\mathrm{LiFe}_{1-y} \mathrm{Mn}_{y} \mathrm{PO}_{4}$ has been investigated [27] at elevated temperature $\left(80^{\circ} \mathrm{C}\right)$ before and after high-temperature carbon-coating treatment. It was shown that the discharge capacity, kinetics, and cycling stability were all improved after the heating process. The observed capacity values of $80 \mathrm{mAh} \cdot \mathrm{g}^{-1}$ (> 54\% of the theoretical value) were much smaller than for the synthetic samples, suggesting that impurities present in natural triphylites as well as inappropriate sample morphology might create problems; for that reason, all battery cathode materials are synthetic [7].

Today, lithium-iron phosphate, $\mathrm{LiFePO}_{4}$, stands as a commercialized cathode material in LIBs for hybrid vehicles and grid storage systems. The development of new approaches for the synthesis of materials such as the transition to nanostructured $\mathrm{LiFePO}_{4}$ material, creating a conductive carbon coating on the surface of the active material particles and surface doping, significantly improved the mass transfer rate. These state-of-the-art methods led to the high-rate $\mathrm{LiFePO}_{4}$ material, which demonstrates a specific capacity close to its theoretical value [28-30]. Computational methods (density functional theory and molecular dynamics) also contributed to exploration of the new synthesis approaches. It was found that Li-ion diffusion in $\mathrm{LiFePO}_{4}$ is strongly anisotropic and occurs through a curved path along the $\{010\}$ direction, and later on, Nishimura et al. provided experimental evidence for this curved one-dimensional (1D) path for lithium motion [31-33]. These findings prompted the development of $\mathrm{LiFePO}_{4}$ material with specific morphology, which was prepared by hydrothermal and solvothermal approaches $[34,35]$.

Further development of the functional properties of $\mathrm{LiFePO}_{4}$ material are directed towards increasing specific energy and power characteristics: today, materials based on $\mathrm{Li}(\mathrm{Fe}, \mathrm{Mn}) \mathrm{PO}_{4}$ are actively investigated. It is found that the partial substitution of iron by manganese not only leads to an increase of the working potential of the material and consequently its energy density but also changes the mechanism of Li extraction/insertion [36].

\subsubsection{Lithiophilite-Purpurite-Niahite: Comparative Crystal Chemistry and Structure Transformation}

A topological analysis reveals similar fragments forming crystal structure types of the triphylite-lithiophilite and niahite, $\left(\mathrm{NH}_{4}\right) \mathrm{MnPO}_{4}\left(\mathrm{H}_{2} \mathrm{O}\right)$, mineral groups [37,38]. Niahite has a biogenic nature; it was found in a limestone cave with bat guano in Malaysia [39]. The mineral crystal structure was not solved because of the very soft and fragile nature of niahite. The crystal structures of related 
synthetic varieties with formulae $\mathrm{NH}_{4}\left[\mathrm{Fe}\left(\mathrm{PO}_{4}\right)\right] \mathrm{HF}$ and $\left(\mathrm{NH}_{4}\right) \mathrm{CoPO}_{4} \cdot \mathrm{H}_{2} \mathrm{O}$ have been studied. Lately, a full formula analogue of mineral $\mathrm{NH}_{4} \mathrm{MnPO}_{4}\left(\mathrm{H}_{2} \mathrm{O}\right)$ obtained under low-temperature hydrothermal conditions, so-called "chemie douce" [40], was structurally investigated [41].

In the crystal structure of niahite, $\mathrm{Mn}^{2+}$ has octahedral coordination where five vertices are occupied by phosphate $\mathrm{O}$ atoms and one by the $\mathrm{O}$ atom of the $\mathrm{H}_{2} \mathrm{O}$ molecule. The Mn-centered octahedra share common $\mathrm{O}$ vertices to form two-dimensional (2D) quadratic layers parallel to the $b c$ plane of the unit cell (Figure 2). The $\mathrm{PO}_{4}$ tetrahedra share one edge and one vertex with $\mathrm{MnO}_{6}$ octahedra. They are placed at capping positions alternating above and below the square meshes of the $\mathrm{MnO}_{6}$ layer. One of four vertices of each $\mathrm{PO}_{4}$ tetrahedron is not coordinated to Mn but is directed towards the interlayer space where $\mathrm{NH}_{4}$ groups are placed (Figure 3). As this terminal $\mathrm{O}$ atom is bonded only to $\mathrm{P}^{5+}$ in the structure and therefore has a formal bond valence of 1.25 , which is too small, it becomes an acceptor of four possible hydrogen bonds from the ammonium ions. The mixed Mn, $\mathrm{P}$ sheets are linked along the $\{100\}$ direction by three $\mathrm{N}-\mathrm{H} \cdots \cdot \mathrm{O}$ hydrogen bonds in a three-dimensional construction. Additional hydrogen bonding occurs along the layer planes from the aqua ligands towards the phosphate oxygen atoms. These $\mathrm{O}-\mathrm{H} \cdots \cdot \mathrm{O}$ hydrogen bonds are bifurcated.
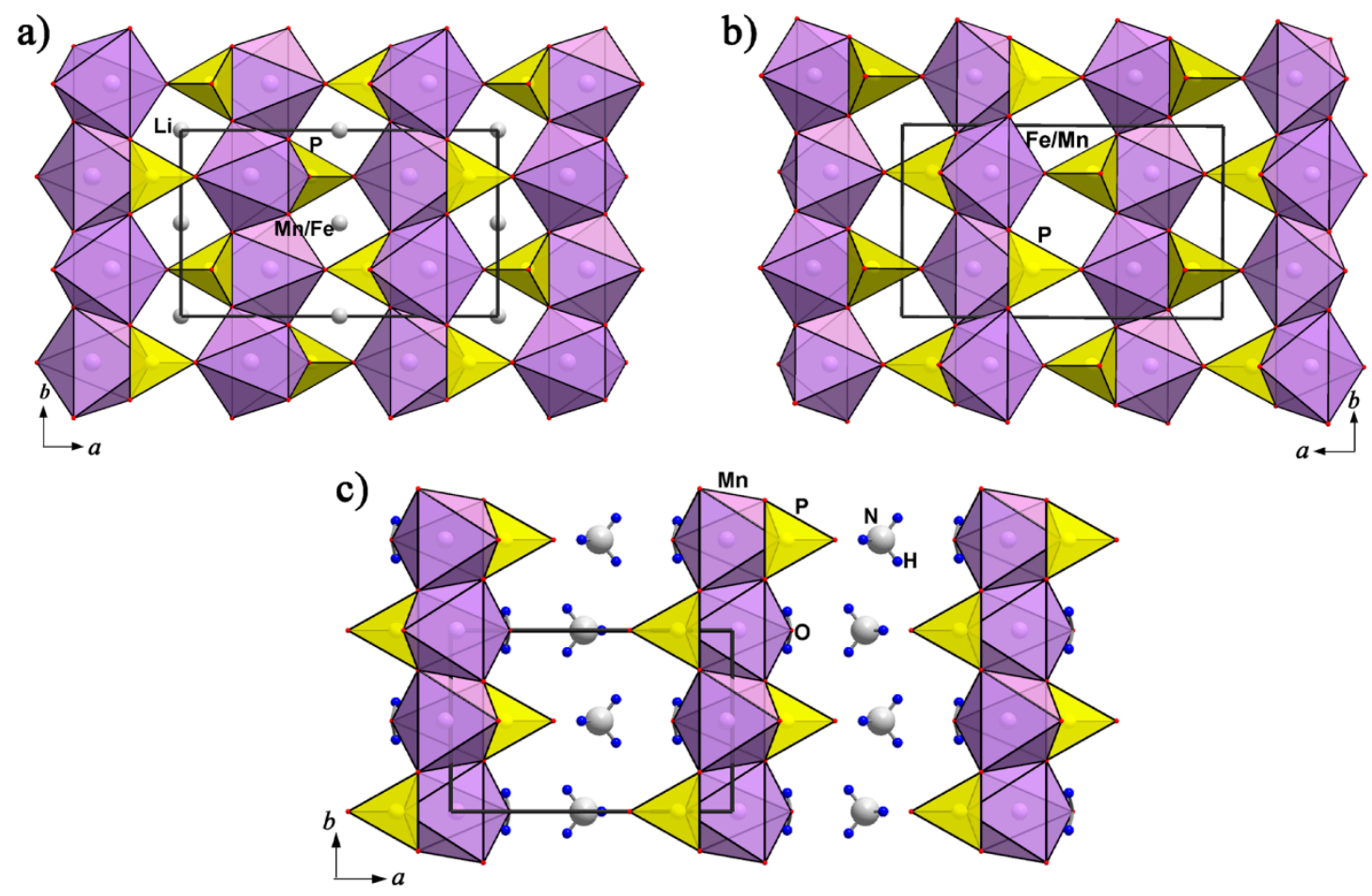

Figure 3. Triphylite-(a), heterosite-(b), and niahite-(c) type crystal structures shown along the $c$ axis of the orthorhombic unit cells.

The plate-like habitus of the crystals corresponds to the layer structure; the $a$ axis is normal to the crystal-plate. The mixed $\mathrm{Mn}, \mathrm{P}$ layers in the niahite $\mathrm{NH}_{4} \mathrm{MnPO}_{4}\left(\mathrm{H}_{2} \mathrm{O}\right)$ structure can be interpreted as fragments of the lithiophilite, $\mathrm{Li}(\mathrm{Mn}, \mathrm{Fe}) \mathrm{PO}_{4}$, or purpurite, $(\mathrm{Mn}, \mathrm{Fe}) \mathrm{PO}_{4}$, structure. All minerals are orthorhombic, their space groups differ within the inversion center, and the unit cell volumes are close. There are two Mn, P layers parallel to the $b c$ plane of the same topology in the unit cell of purpurite (and lithiophilite) (Figure 2). These layers connect in the $\{100\}$ direction through common vertices of $\mathrm{Mn}$ - and $\mathrm{P}$ - centered polyhedra. Every second layer of $\mathrm{MnO}_{6}$ octahedra with adjacent $\mathrm{PO}_{4}$ tetrahedra may be extracted from the structure of purpurite to provide a model of the $\left[\mathrm{Mn}\left(\mathrm{PO}_{4}\right)\right]$ layer in niahite, stabilized by terminal aqua ligands. The $\mathrm{NH}_{4}{ }^{+}$cations between the sheets supply the interlayer connection along the $\{100\}$ direction to form the crystal structure of niahite, $\mathrm{NH}_{4} \mathrm{MnPO}_{4}\left(\mathrm{H}_{2} \mathrm{O}\right)$ (Figure 3). In nature, this mechanism may occur during a bioorganic process under reducing conditions with formation of the mineral niahite, $\left(\mathrm{NH}_{4}\right) \mathrm{MnPO}_{4}\left(\mathrm{H}_{2} \mathrm{O}\right)$, after purpurite, $\mathrm{MnPO}_{4}$, and lithiophilite, 
$\mathrm{Li}(\mathrm{Mn}, \mathrm{Fe}) \mathrm{PO}_{4}$. As in the case of the triphylite-heterosite conversion in hydrothermal conditions, this process can run without a rearrangement of the mother structure: the newly forming compound adopts its basic fragments.

A supposition regarding possible lithiophilite $\rightarrow$ niahite transformation $[37,38]$ was indirectly supported by experimental works on the preparation of synthetic analogues of minerals of the triphylite-lithiophilite series using the "niahite" matrix $\mathrm{NH}_{4} M \mathrm{MO}_{4} \cdot \mathrm{H}_{2} \mathrm{O}(M=\mathrm{Fe}, \mathrm{Mn}, \mathrm{Co}$, or Ni) as precursor [42-44]. The $\mathrm{LiFePO}_{4} / \mathrm{C}$ (coated with carbon) material, synthesized using the "niahite" precursor, demonstrated high rate capability with capacity values close to the theoretical one, while the $\mathrm{LiMnPO}_{4} / \mathrm{C}$ sample showed much lower capacity values. The preservation of precursor morphology was also observed upon replacement of $\mathrm{NH}_{4}{ }^{+}$groups by $\mathrm{Li}^{+}$cations through solid-state reaction at elevated temperature: the obtained $\mathrm{LiMPO}_{4}$ particles completely repeat the shape of the intermediate $\mathrm{NH}_{4} M \mathrm{PO}_{4} \cdot \mathrm{H}_{2} \mathrm{O}$ crystals $(M=\mathrm{Fe}, \mathrm{Mn})$ [44].

4.1.3. Simferite, $\mathrm{Li}\left(\mathrm{Mg}, \mathrm{Fe}^{3+}, \mathrm{Mn}^{3+}\right)_{2}\left(\mathrm{PO}_{4}\right)_{2}$ and Tavorite, $\mathrm{LiFe}\left(\mathrm{PO}_{4}\right)(\mathrm{OH}, \mathrm{F})$ Based Materials and Their Electrochemical Potential

The secondary pegmatite mineral simferite, $\mathrm{Li}\left(\mathrm{Mg}, \mathrm{Fe}^{3+}, \mathrm{Mn}^{3+}\right)_{2}\left(\mathrm{PO}_{4}\right)_{2}$, is structurally very close to triphylite or lithiophilite, although it contains $\mathrm{Mg}$ and atoms of transition metals in 3+ oxidation state. The crystal structure refinement of simferite established that $\mathrm{Li}^{+}$statistically occupies one half of $M 1$ positions at the center of symmetry, while the octahedral $M 2$ position is populated by $\mathrm{Mg}, \mathrm{Fe}^{3+}$, and $\mathrm{Mn}^{3+}$ in a ratio of 0.5:0.3:0.2 [45]. Simferite happened to be another mineral, which motivated researchers to synthesize and study its laboratory analogous.

To understand the phase transformation behavior of triphylite electrode materials upon Li-deintercalation, the effect of $\mathrm{Mg}$ substitution in $\mathrm{LiFe}_{0.6} \mathrm{Mn}_{0.4} \mathrm{PO}_{4}$ has been investigated [46]. It was demonstrated that, in contrast to the equilibrium two-phase nature of $\mathrm{LiFePO}_{4}$, the simferite-like compound $\mathrm{Li}_{x} \mathrm{Mg}_{0.5} \mathrm{Fe}_{0.3} \mathrm{Mn}_{0.2} \mathrm{PO}_{4}$ undergoes a single-phase reaction mechanism, providing faster rate kinetics. Moreover, a continuous increase in the voltage of the $\mathrm{Mn}^{2+} / \mathrm{Mn}^{3+}$ redox couple on the addition of $\mathrm{Mg}$ to $\mathrm{LiMn}_{0.4} \mathrm{Fe}_{0.6} \mathrm{PO}_{4}$ was reported.

A rare mineral of lithium pegmatites, tavorite, $\mathrm{LiFePO}_{4}(\mathrm{OH}, \mathrm{F})$, is a product of hydrothermal transformation of triphylite and usually occurs with barbosalite, ferrisicklerite, and heterosite [13]. The tavorite crystal structure (Figure 4 ) is composed of centrosymmetric $\mathrm{Fe}^{3+}$ - centered octahedra sharing $\mathrm{OH}$ vertices to form columns running along the $b$ axis. Along the $a$ and $c$ directions, these columns are joined through $\mathrm{PO}_{4}$ tetrahedra in a framework with $\mathrm{Li}^{+}$cations in its cavities. The $\mathrm{LiO}_{5}$ polyhedra share edges to form pairs linked along the $c$ axis by phosphate tetrahedra.

a)

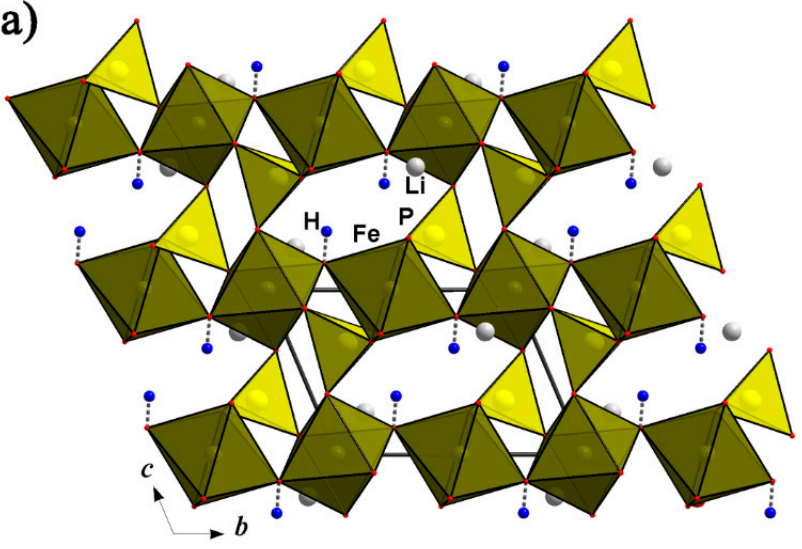

b)

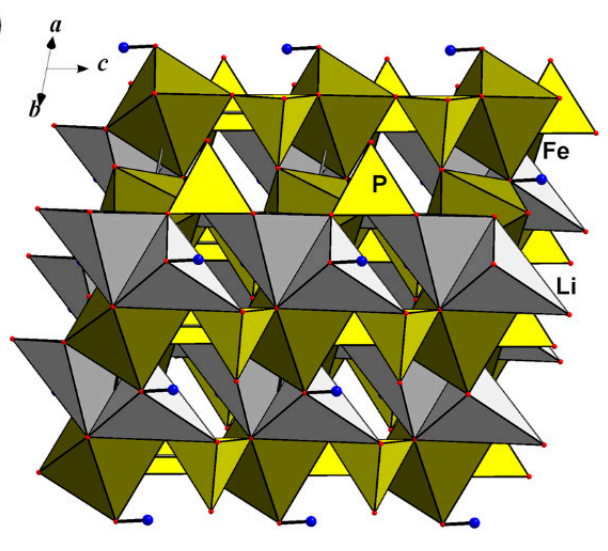

Figure 4. The tavorite, $\mathrm{LiFe}\left(\mathrm{PO}_{4}\right)(\mathrm{OH})$, crystal structure in $y z$ projection with $\mathrm{Li}^{+}$ions shown as light gray spheres (a) and along $\{110\}$ direction, with quasi chains of edge-sharing pairs of Li-centered five-vertex polyhedra parallel to the $c$ axis (b). 
Black crystals of the octahedral shape, obtained under hydrothermal conditions and identified by $X$-ray diffraction as tavorite, have been studied in order to understand a supposal $\mathrm{Fe}^{2+} \rightarrow \mathrm{Fe}^{3+}$ charge transfer responsible for the crystals' coloring [47]. A precise crystal structure analysis of a spherical sample, including investigation of the deformation electron density, revealed an additional position in the octahedral surrounding of $\mathrm{O}$ atoms (Figure 4a). This position with small occupancy was identified as statistically populated by $\mathrm{Fe}^{2+}$ ions [48]. An Fe-Fe distance of $2.556 \AA$ etween the centers of three octahedra sharing faces (so-called "h clusters"), which form when additional octahedra are populated by $\mathrm{Fe}^{3+}$ ions, led to the charge transfer between neighboring Fe atoms. The crystal chemical formula of the $\mathrm{Fe}^{3+}$-bearing tavorite (for simplicity of presentation of the material, we use mineral names when identifying synthetic analogues that are employed in battery technology) was established as $\left.\mathrm{LiFe}^{3+} \mathrm{Fe}^{2+}{ }_{x}\left[\mathrm{PO}_{4}\right](\mathrm{OH})_{1-2 x} \mathrm{O}_{2 x}\right]$; this formula describes a correlation between amounts of $\mathrm{Fe}^{2+}$ and $\mathrm{H}^{+}$ cations. It is important to mention that the crystal structure allows a maximal number of $\mathrm{Fe}^{2+}$ in the additional position at the center of symmetry $(0,0.5,0.5)$ of triclinic space group $P \overline{\mathbf{1}}$ up to an $x$ value equal to 0.5 . If this limit is achieved, the $\mathrm{Fe}^{2+}$ ions would become ordered in their site, the hydroxyl groups would disappear, and the $\mathrm{Fe}^{3+}: \mathrm{Fe}^{2+}$ ratio would become equal to 2:1.

Synthetic $\mathrm{LiFePO}_{4}(\mathrm{OH})$ was tested as the positive electrode, and electrochemical activity with a reversible capacity of around $100 \mathrm{mAh} \cdot \mathrm{g}^{-1}$, corresponding to the insertion of additional $\mathrm{Li}$, was observed at an average voltage of $2.3 \mathrm{~V} \mathrm{vs} \mathrm{Li} / \mathrm{Li}^{+}$[49]. $\mathrm{LiVPO}_{4} \mathrm{~F}$ is one of the most studied fluoride-phosphates with the tavorite structure. The incorporation of a fluorine ion in the coordination sphere of the transition metal "enhances" the inductive effect of $\left(\mathrm{PO}_{4}\right)$-groups, increasing the potential of the $\mathrm{V}^{3+} / \mathrm{V}^{4+}$ redox transition up to $4.2 \mathrm{~V}$ vs. $\mathrm{Li} / \mathrm{Li}^{+}$. Furthermore, $\mathrm{LiVPO}_{4} \mathrm{~F}$ demonstrates the feasibility of multi-electronic activity based on the multivalent nature of vanadium with the reversible insertion of additional $\mathrm{Li}\left(\mathrm{V}^{3+} / \mathrm{V}^{2+}\right.$ redox transition) at $1.8 \mathrm{~V}[50]$.

\subsubsection{Na-Bearing Triphylite-Lithiophilite Structural Analogous and Their Derivatives as Promising} Cathode Materials

The olivine $(\mathrm{Mg}, \mathrm{Fe})_{2}\left(\mathrm{SiO}_{4}\right)$ structure turned out to be very stable; many compounds of different compositions, such as silicates, phosphates, germanates, borates, and so on, crystallize in this structure type. It is based on hexagonal close packing of $\mathrm{O}$ atoms with cations partly occupying octahedral and tetrahedral voids. Several pegmatite phosphates, namely the above-discussed minerals of the triphylite $\mathrm{Li}(\mathrm{Fe}, \mathrm{Mn}) \mathrm{PO}_{4}$-lithiophilite $\mathrm{Li}(\mathrm{Mn}, \mathrm{Fe}) \mathrm{PO}_{4}$, ferrisicklerite $\mathrm{Li}_{1-x}\left(\mathrm{Fe}^{3+}{ }_{x} \mathrm{Fe}^{2+}{ }_{1-x}\right) \mathrm{PO}_{4}$-sicklerite $\mathrm{Li}_{1-x}\left(\mathrm{Mn}^{3+}{ }_{x} \mathrm{Mn}^{2+}{ }_{1-x}\right) \mathrm{PO}_{4}$, and heterosite $\left(\mathrm{Fe}^{3+}, \mathrm{Mn}^{3+}\right) \mathrm{PO}_{4}$-purpurite $\left(\mathrm{Mn}^{3+}, \mathrm{Fe}^{3+}\right) \mathrm{PO}_{4}$ series, besides the $\mathrm{Na}$ analogues natrophilite, $\mathrm{Na}(\mathrm{Mn}, \mathrm{Fe}) \mathrm{PO}_{4}$, and karenwebberite, $\mathrm{Na}(\mathrm{Fe}, \mathrm{Mn}) \mathrm{PO}_{4}$, have olivine-type structures with alkali cations occupying positions in the core of "olivine tape" and atoms of transition metal in the "teeth" (Figure 5a). The movement of alkali ions along these tapes defines intercalation chemistry of the corresponding phosphates.

There are two natural sodium phosphates that are isotypic with lithiophilite-triphylite series' members, namely karenwebberite, $\mathrm{Na}(\mathrm{Fe}, \mathrm{Mn}) \mathrm{PO}_{4}$, and natrophilite, $\mathrm{Na}(\mathrm{Mn}, \mathrm{Fe}) \mathrm{PO}_{4}$. Karenwebberite is an extremely rare mineral; it was found in 2011 as a late-magmatic-stage exsolution product within graftonite nodules in association with Na-bearing ferrisicklerite and a heterosite-like phase [51]. Karenwebberite is not a thermodynamically stable phase, which means it cannot be obtained using conventional chemical methods. The obvious reason for the thermodynamic instability of both the mineral and its synthetic analogues is that $\mathrm{Na}^{+}$ions are too large to occupy positions in the centers of the octahedra forming the olivine tape core. In the structures of the minerals of the triphylite-lithiophilite series, these sites are populated by smaller $\mathrm{Li}^{+}$ions. The same paradox, which was already analyzed in 1972 , is connected with the crystal structure of natrophilite, $\mathrm{NaMnPO}_{4}$. At that moment it was the only representative of an ordered olivine type structure with the $M 1$ sites populated by cations $\left(\mathrm{Na}^{+}\right)$that are significantly larger than the cations in the $M 2$ sites $\left(\mathrm{Mn}^{2+}\right)$, with a radius ratio of $\mathrm{r}_{\mathrm{M} 1}: \mathrm{r}_{\mathrm{M} 2}=1.24$ [52]. Similar to karenwebberite, the natrophilite deposits are single. They are known in granitic pegmatites, where the mineral is associated with lithiophilite in accordance with the conclusion of Moore [52]: 
"Since $\mathrm{Mn}^{2+}$ is more resistant than $\mathrm{Fe}^{2+}$ to oxidation in crystals and in solution, potential natrophilite occurrences should be found only where the lithiophilite member prevails; such localities are few and the products are at least partially oxidized".

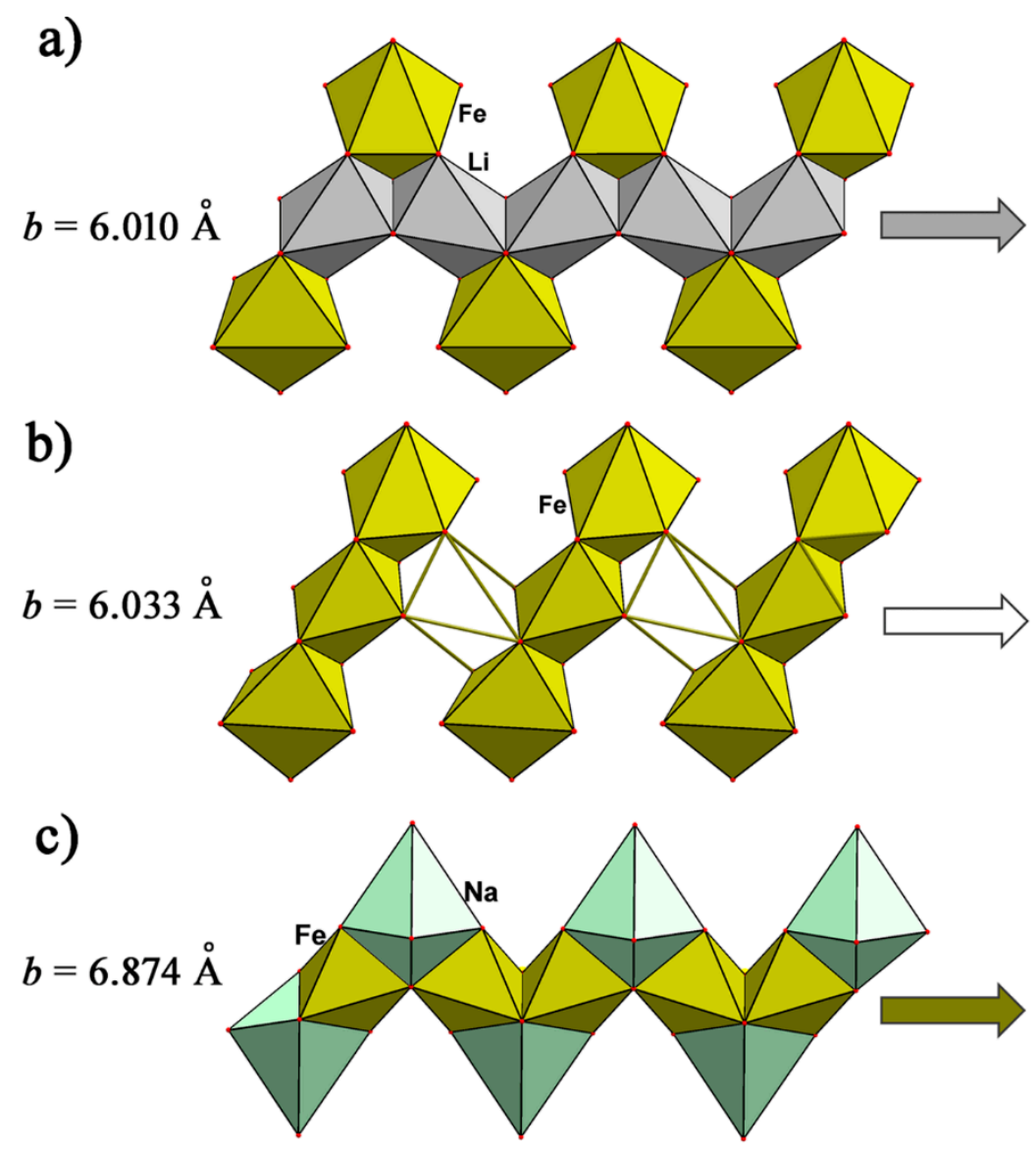

Figure 5. "Olivine tapes" aligned in the $\{010\}$ direction in the crystal structure types of triphylite, $\mathrm{LiFePO}_{4}$ (simferite with one half of $\mathrm{LiO}_{6}$ octahedra statistically vacant) (a), sarcopside, $\mathrm{Fe}_{1.5} \mathrm{PO}_{4}(\mathbf{b})$, and marićite, $\mathrm{NaFePO}_{4}(\mathbf{c})$.

Triphylite-type $\mathrm{NaFePO}_{4}$ can be prepared by an ion-exchange method from $\mathrm{LiFePO}_{4}$ [53]: Li-ions are chemically or electrochemically extracted from triphylite, $\mathrm{LiFePO}_{4}$, forming heterosite, $\mathrm{FePO}_{4}$. Further chemical (and electrochemical) $\mathrm{Na}$ intercalation into $\mathrm{FePO}_{4}$ heterosite results in the formation of triphylite-type $\mathrm{NaFePO}_{4}$. This phase is stable below $480{ }^{\circ} \mathrm{C}$; above this temperature, it transforms into marićite, $\mathrm{NaFePO}_{4}$ [54]. In a Na-cell, it reversibly de/intercalates nearly one mole of Na ions with two voltage plateaus on the discharge curve (at 2.87 and $2.97 \mathrm{~V}$ ), which originate from the appearance of an intermediate sodium-ordered phase [55].

A karenwebberite dimorph, the thermodynamically stable orthorhombic mineral maricite, $\mathrm{Na}(\mathrm{Fe}, \mathrm{Mn}) \mathrm{PO}_{4}$ [56], may be considered, from the structural point of view, as a triphylite derivative with $\mathrm{Fe}^{2+}$ ions occupying positions at the symmetry centers $(M 1)$ and $\mathrm{Na}^{+}$ions placed in the positions with m symmetry (M2), just opposite to the distribution of these atoms in the crystal structure of karenwebberite (Figure 5). This kind of structure transformation leads to strong distortion of hexagonal close packing of $\mathrm{O}$ atoms inherent to the triphylite structure. The reasons for this distortion are the large $\mathrm{Na}^{+}$cations, which transform the olivine tape when incorporated in its teeth through sharing two neighboring faces of $\mathrm{NaO}_{6}$ with $\mathrm{FeO}_{6}$ octahedra (Figure $5 \mathrm{c}$ ). The reconstruction leads to the growth of the unit cell $b$ parameter parallel to the olivine tape, compared to that of the triphylite unit cell, and lowering of the $a$ parameter perpendicular to the tape [57]. As shown experimentally in [58], the polymorphic transformation from marićite-type to olivine-type crystal structure occurs 
in the region of $325^{\circ} \mathrm{C}(\mathrm{P}=100$ bars $)$. According to [51], following the $\mathrm{Fe}^{2+}$ oxidation mechanism, karenwebberite transforms into a dark brown $\mathrm{Na}$ analog of ferrisicklerite, $\mathrm{Na}_{1-x}\left(\mathrm{Fe}^{3+}, \mathrm{Mn}^{2+}\right)\left(\mathrm{PO}_{4}\right)$.

Synthetic maricite has been considered as electrochemically inactive because sodium sites are isolated in the structure, and a large barrier to sodium migration is expected [54]. The structural transformation associated with the opposite distribution of alkali and transition metal atoms to that of karenwebberite locks the channels along the $\{010\}$ direction preventing movements of Na-ions. The alternative channels parallel to the $\{011\}$ direction with small open windows (Figure 6) are also characterized by high activation energy for Na-ion diffusion $(>1.5 \mathrm{eV}$, in contrast to values ranging between 0.2 and $0.6 \mathrm{eV}$ in conventional battery materials) [59]. It was found that upon first charge in a Na-cell, maricite, $\mathrm{NaFePO}_{4}$, with nanoparticle morphology undergoes structural transformation, resulting in nucleation and growth of the amorphous $\mathrm{FePO}_{4}$, and this transformed phase delivers a capacity of $142 \mathrm{mAh} \cdot \mathrm{g}^{-1}$ (92\% of the theoretical value) and shows remarkable cyclability with a negligible capacity fade [59].

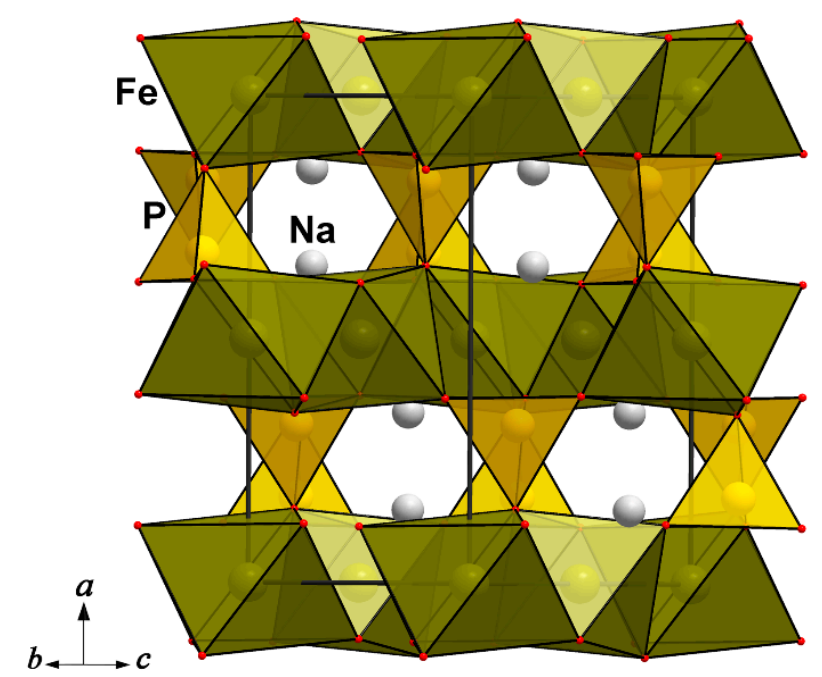

Figure 6. The crystal structure of marićite projected along the $\{011\}$ direction shows open channels with small windows.

One more mineral structurally related to triphylite, sarcopside, $\mathrm{Fe}_{3}\left[\mathrm{PO}_{4}\right]_{2}$, has never been observed as a primary crystal phase [60]. According to Moore, 1972 [60], sarcopside is an exsolved phase associated either with graftonite or triphylite. The sarcopside crystal structure is based on hexagonal close packing of oxygen atoms in which three-eighths of the octahedral and one-eighth of the tetrahedral voids are filled. It may be interpreted as the triphylite's derivative. The structural transformation from triphylite to sarcopside is reconstructed as Li leaching from the M1 positions in the octahedra of the "olivine tape" and subsequent ordered occupation of one half of them by Fe atoms (Figure 5b). The ordered distribution of Fe inside the core of the tape dictates a decrease in symmetry from orthorhombic (in triphylite) to monoclinic (Figure 5b). The crystal chemical ordering relationship between triphylite and sarcopside may be described after Moore, 1972, as:

triphylite, $\mathrm{Li}_{4} \mathrm{Fe}_{4}\left(\mathrm{PO}_{4}\right)_{4}$ (sp. group Pnma) $\rightarrow$ sarcopside $\left(\square_{2} \mathrm{Fe}_{2}\right) \mathrm{Fe}_{4}\left(\mathrm{PO}_{4}\right)_{4}$ (sp. group $P 112_{1} / a$ ), where $\square$ indicate ordered vacancies; $Z=1$.

The similarity of triphylite, sarcopside, and heterosite crystal structures is an obvious starting point for studies of the electrochemical characteristics of their synthetic analogues. Thus, to explain the positive effect of vanadium doping on Li-ion transport, the formation of sarcopside defects in $\mathrm{LiV}_{y} \mathrm{Fe}_{1-3 / 2 y} \mathrm{PO}_{4}$ material was suggested. Whittingham's group confirmed that upon doping, vanadium indeed occupies Fe sites, but some Fe exists at Li sites within sarcopside clusters, leaving a large percentage of the tunnels free for lithium diffusion [61]. Sarcopside defects were also reported in a 
transmission electron microscopy study of single crystals of $\mathrm{LiFePO}_{4}$ with some excess iron (no more than 1\%) compared to the stoichiometric composition [62].

As one can see on comparing the triphylite and sarcopside crystal structures presented in the same projection (Figure 7), the closure of Li migration paths along the $b$ axis during heterovalent substitution by Fe can be at least partly compensated by the remaining channels parallel to the $\{001\}$ direction (Figure 7a,b). These channels are formed by Li-centered octahedra alternating along the $c$ axis with small interstitial cavities of an octahedral shape, which share two opposite faces with phosphate tetrahedra (Figure 7c). However, participation of these interstitial cavities in Li-ion diffusion is unlikely, even as intermediate positions, because of the high activation energy revealed by computational studies [31,32].

a)

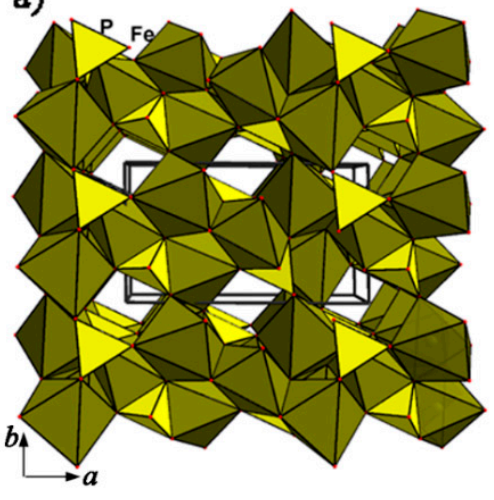

b)

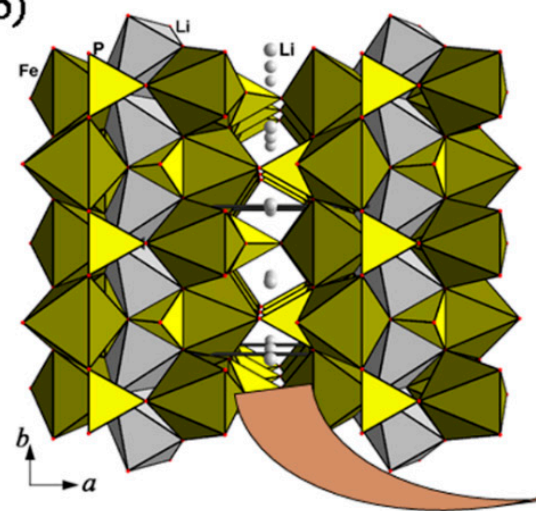

c)

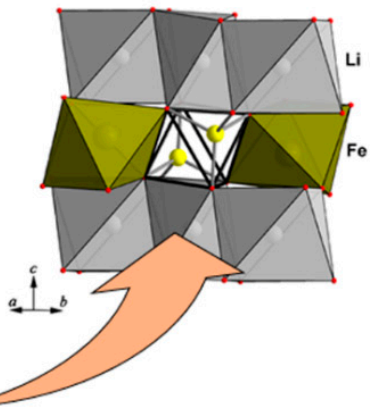

Figure 7. The sarcopside (a) and triphylite (b) crystal structures in axonometric projection along the $c$ axis. A fragment of the triphylite structure with small octahedral interstitium in constricted channels, parallel to the $\{001\}$ direction (c).

Peculiarities of the hydrothermal synthesis of the lithium iron phosphate cathode material were studied in situ, by Calvet calorimetry and appearance of the intermediate with sarcopside structure was indicated. It was found that depending on the initial precursor concentration, the formation of this "antisite iron phosphate" and the reaction with $\mathrm{Li}^{+}$to produce the final $\mathrm{LiFePO}_{4}$ phase can take place as two consecutive stages or as merging of these two stages into one. The observed changes in the reaction mechanism result in profound difference in the unit cell parameters of the triphylite phase, particle morphology, and electrochemical properties of the obtained $\mathrm{LiFePO}_{4}$ samples [35].

According to [63], direct thermal oxidation of sarcopside, $\mathrm{Fe}_{3}\left(\mathrm{PO}_{4}\right)_{2}$, above $450{ }^{\circ} \mathrm{C}$, makes it possible to obtain heterosite, $\mathrm{FePO}_{4}$, according to the reaction $\mathrm{Fe}_{3}\left(\mathrm{PO}_{4}\right)_{2}+3 / 4 \mathrm{O}_{2} \rightarrow 2 \mathrm{FePO}_{4}+1 / 2 \mathrm{Fe}_{2} \mathrm{O}_{3}$, which leads to the extraction of iron from the sarcopside structure. The authors note that the oxidized product demonstrates electrochemical performances consistent with those of heterosite, $\mathrm{FePO}_{4}$.

\subsection{Other Phosphate-Based Series}

\subsubsection{Mineral Kosnarite and Structurally Related Phosphates}

A late alteration mineral of granitic pegmatites, kosnarite, $\mathrm{KZr}_{2}\left(\mathrm{PO}_{4}\right)_{3}$, was discovered in the early 1990s as part of a late-stage, secondary phosphate mineral assemblage [64]. The crystal structure of its synthetic analogue was determined in 1969 [65]. The kosnarite crystal structure presents a 3D framework built from $\mathrm{ZrO}_{6}$ octahedra and $\mathrm{PO}_{4}$ tetrahedra linked through oxygen-bridge contacts (Figure 8). Each octahedron shares all six oxygen vertices with tetrahedra, and conversely, each tetrahedron shares four vertices with the surrounding octahedra. The mixed-type anionic framework $\left[\mathrm{Zr}_{2} \mathrm{P}_{3} \mathrm{O}_{12}\right]^{-}$is dense in the whole unit cell except at $\overline{3}$, where holes exist between the zirconium polyhedra. The $\mathrm{K}^{+}$cations are located in these holes at the centers of trigonal antiprisms surrounded by six $\mathrm{O}$. 
a)

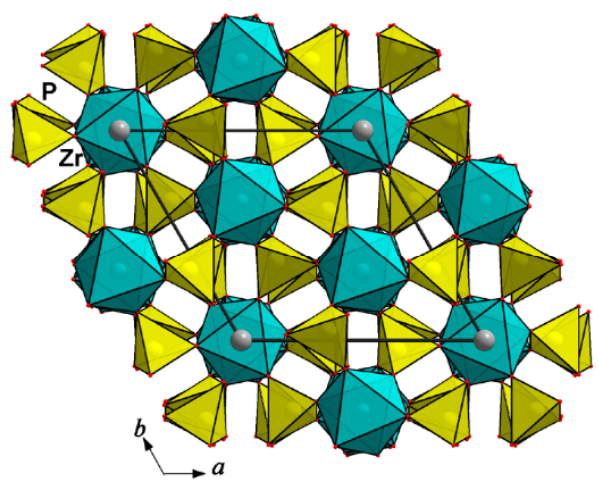

b)

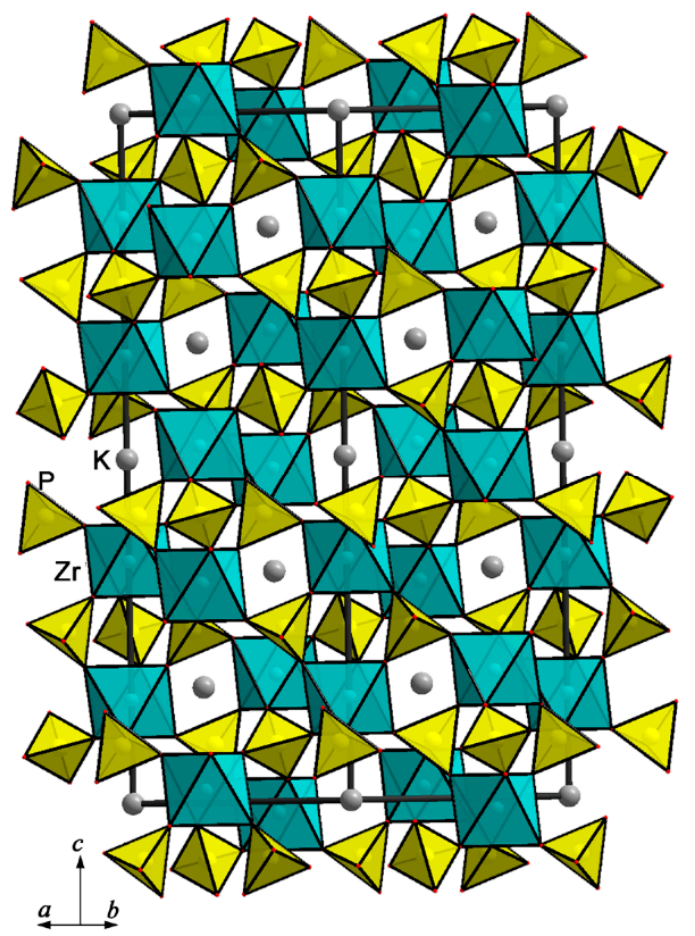

Figure 8. The crystal structure of kosnarite in $x y$ projection (a) and along $\{110\}$ direction (b).

A large group of synthetic phases with crystal structures close to that of kosnarite belongs to the so-called NASICON family (Na Super Ionic CONductor). Depending on the valence state of the atoms, forming a mixed anionic framework in association with $\mathrm{PO}_{4}$ tetrahedra, and on their size, the number of alkali cations in the kosnarite-type structure changes from zero to five per formula unit. Li-containing phosphate compositions, $\mathrm{Li}_{3} \mathrm{M}_{2}\left(\mathrm{PO}_{4}\right)_{3}(\mathrm{M}=\mathrm{Fe}, \mathrm{V})$, adopt two distinct crystallographic forms: rhombohedral $(R \overline{3})$ referred to as NASICON, and monoclinic $\left(P 2_{1} / n\right)$, referred to as anti-NASICON, which differ in the way the $M_{2}\left(\mathrm{PO}_{4}\right)_{3}$ lantern units are connected [8]. The monoclinic phase is the stable form, prepared via solid-state reaction, whereas the rhombohedral $\mathrm{Li}_{3} \mathrm{M}_{2}\left(\mathrm{PO}_{4}\right)_{3}$ is obtained through ion exchange from the NASICON sodium analogues, $\mathrm{Na}_{3} \mathrm{M}_{2}\left(\mathrm{PO}_{4}\right)_{3}(\mathrm{M}=\mathrm{Fe}, \mathrm{V})[66,67]$. Thus, two rhombohedral crystal structures of homeotypes of kosnarite, $\mathrm{Na}_{3} \mathrm{M}_{2}\left(\mathrm{PO}_{4}\right)_{3}$ [68] and $\mathrm{Li}_{3} \mathrm{M}_{2}\left(\mathrm{PO}_{4}\right)_{3}$, have the same 3D framework $\left[\mathrm{M}_{2} \mathrm{P}_{3} \mathrm{O}_{12}\right]$. The main difference is connected with the quantity, distribution, and coordination numbers of $\mathrm{Na}$ or $\mathrm{Li}$ atoms in the framework's cavities. According to [69], there are two symmetrically independent sites for $\mathrm{Na}$ atoms in the $\mathrm{Na}_{3} \mathrm{M}_{2}\left(\mathrm{PO}_{4}\right)_{3}$ kosnarite-type structure crystallizing in the same $R \overline{3} c$ space group, both partly populated by Na atoms with six and eight oxygen atoms in their first coordination sphere. Differently, Li atoms in tetrahedral coordination occupy one general type position in the framework cavities. In recent years, polyanionic frameworks within the NASICON structural family were heavily investigated due to their specific 3D framework structure, stable long-term cycling ability, and high alkali ion diffusion rate [70].

Rhombohedral $\mathrm{Li}_{3} \mathrm{~V}_{2}\left(\mathrm{PO}_{4}\right)_{3}$ with the $\mathrm{V}^{3+} / \mathrm{V}^{4+}$ redox couple has been identified as a high voltage cathode material with a theoretical capacity of $131 \mathrm{mAh} \cdot \mathrm{g}^{-1}$, corresponding to the extraction of two $\mathrm{Li}^{+}$ions. It demonstrates discharge curves with the flat plateau at around $3.75 \mathrm{~V}\left(\mathrm{vs} . \mathrm{Li} / \mathrm{Li}^{+}\right)$, while the monoclinic phase exhibits a more complicated behavior with multiple transitions in the discharge curves [8]. The reversible Li-insertion into rhombohedral phase at an average potential of $1.75 \mathrm{~V}$ (vs. $\mathrm{Li} / \mathrm{Li}^{+}$) was observed, indicating that it can be applied as an anode material as well. The material delivered capacity values close to theoretical values for both types of activities (121 $\mathrm{mAh} \cdot \mathrm{g}^{-1}$ for the cathode and $117 \mathrm{mAh} \cdot \mathrm{g}^{-1}$ for the anode), with excellent rate capability and long cycling performance [71]. In contrast to the rhombohedral phase, monoclinic $\mathrm{Li}_{3} \mathrm{~V}_{2}\left(\mathrm{PO}_{4}\right)_{3}$ exhibits reversible extraction of three $\mathrm{Li}$ ions, with activation of the $\mathrm{V}^{3+} / \mathrm{V}^{4+}$ and $\mathrm{V}^{4+} / \mathrm{V}^{5+}$ redox couples, which 
corresponds to high specific capacity $\left(197 \mathrm{mAh} \cdot \mathrm{g}^{-1}\right)$. Nevertheless, properties of this material will not be discussed, because although the structure of monoclinic $\mathrm{Li}_{3} \mathrm{~V}_{2}\left(\mathrm{PO}_{4}\right)_{3}$ is closely related, it still differs from the structure of kosnarite.

$\mathrm{Na}_{3} \mathrm{~V}_{2}\left(\mathrm{PO}_{4}\right)_{3}$ was shown to be active toward $\mathrm{Na}^{+}$extraction and insertion of additional sodium. Approximately $2 \mathrm{~mol}$ of $\mathrm{Na}$ is extracted from $\mathrm{Na}_{3} \mathrm{~V}_{2}\left(\mathrm{PO}_{4}\right)_{3}$ with a flat operating voltage of $3.3 \mathrm{~V}$ (vs. $\left.\mathrm{Na} / \mathrm{Na}^{+}\right)$. Insertion of one additional mole of $\mathrm{Na}^{+}$into $\mathrm{Na}_{3} \mathrm{~V}_{2}\left(\mathrm{PO}_{4}\right)_{3}$ based on the $\mathrm{V}^{3+} / \mathrm{V}^{2+}$ redox at around $1.5 \mathrm{~V}$ may be applied for the negative electrode performance. Today, this material has been identified as interesting NIB cathode material, possessing satisfactory energy density and high power for an extended cycle life. A large number of special approaches (carbon coating, control of particle shape) have been proposed and applied to improve its electrochemical performances [70]. Complete extraction of $2 \mathrm{Na}$ per formula unit, providing a theoretical capacity of $117 \mathrm{mAh} \cdot \mathrm{g}^{-1}$, is based on the $\mathrm{V}^{3+} / \mathrm{V}^{4+}$ redox couple, and deeper deintercalation with activation of the $\mathrm{V}^{4+} / \mathrm{V}^{5+}$ redox couple at higher voltages may also contribute to increasing the energy density of $\mathrm{Na}_{3} \mathrm{~V}_{2}\left(\mathrm{PO}_{4}\right)_{3}$ materials. To enhance specific energy storage characteristics, various substitutions on the $\mathrm{V}$-site have been investigated, and a new $\mathrm{Na}_{4} \mathrm{MnV}\left(\mathrm{PO}_{4}\right)_{3}$ cathode material has been suggested. In $\mathrm{Na}_{4} \mathrm{MnV}\left(\mathrm{PO}_{4}\right)_{3}$, two redox couples of $\mathrm{Mn}^{2+} / \mathrm{Mn}^{3+}$ and $\mathrm{V}^{3+} / \mathrm{V}^{4+}$ were accessed with two voltage plateaus located at 3.6 and $3.3 \mathrm{~V}$ (vs. $\mathrm{Na} / \mathrm{Na}^{+}$) and a maximum capacity value of $101 \mathrm{mAh} \cdot \mathrm{g}^{-1}$. This material demonstrated long cycling stability (over 1000 cycles) and excellent rate performance, attributed to the uniform morphology of the nanosize particles and to high-speed $\mathrm{Na}^{+}$diffusion in the NASICON framework structure [72]. It was found that an additional $\mathrm{Na}^{+}$can be extracted from the $\mathrm{Na}_{4} \mathrm{MnV}\left(\mathrm{PO}_{4}\right)_{3}$ structure, reaching a higher capacity of $156 \mathrm{mAh} \cdot \mathrm{g}^{-1}$ with a new redox activity located at around $3.86 \mathrm{~V}\left(\mathrm{vs} . \mathrm{Na} / \mathrm{Na}^{+}\right)[73]$. It is associated with "unlocking" of the Na1 site in the rhombohedral phase. However, this additional activity is accompanied by relatively fast capacity degradation upon cycling and should be further investigated [74].

\subsubsection{Alluaudite- and Wyllieite-Type Compounds}

At the moment, the alluaudite mineral group counts 30 phosphate and arsenate members, mainly of alkaline and transition metals [75]. Phosphate representatives of the group are associated with pegmatites, while arsenates are found in volcanic deposits and zones of hypergenesis. The first solution of the crystal structure of alluaudite, $\mathrm{NaCaMnFe} 2\left(\mathrm{PO}_{4}\right)_{3}$, was performed by P.B. Moore [76]. According to Moore's paragenetic tree, alluaudites are derivatives of triphylite, lithiophilite, ferrisicklerite, and heterosite by Na-Li metasomatic exchange; most natural samples involve mixed Fe valences and are derivatives of the composition $\mathrm{Na}_{2} \mathrm{Mn}^{2+}\left(\mathrm{Fe}^{2+} \mathrm{Fe}^{3+}\right)\left(\mathrm{PO}_{4}\right)_{3}$. This conclusion is supported by a well-known paragenesis of triphylite, $\mathrm{LiFePO}_{4}$, and alluaudite in pegmatites, and the mineral ferroalluaudite, $\mathrm{Na}_{2} \mathrm{Fe}^{3+} \mathrm{Fe}^{2+}{ }_{2}\left(\mathrm{PO}_{4}\right)_{3}$, can be considered the end product of this transformation. Many experimental proofs of the triphylite $\rightarrow$ alluaudite transformation $[77,78]$ lie in Moore's paradigm of the continuous alteration of triphylite into alluaudite following the scheme $\ll \mathrm{Li}_{3} \mathrm{Fe}^{2+}{ }_{3}\left(\mathrm{PO}_{4}\right)_{3}+2 \mathrm{Na} \rightarrow$ $\mathrm{Na}_{2} \mathrm{Fe}^{3+} \mathrm{Fe}^{2+}{ }_{2}\left(\mathrm{PO}_{4}\right)_{3}+3 \mathrm{Li} »$. This process is accompanied by a triple increase in the unit-cell volume of alluaudite (in comparison with triphylite) and a lowering of symmetry from orthorhombic (in triphylite) to monoclinic (in alluaudite). During the conversion process, layers of $\mathrm{FeO}_{6}$ octahedra sharing vertices in the triphylite structure became transformed into columns of edge-sharing octahedra in the crystal structure of alluaudite. Despite the difference in the assemblies of the Fe-centered octahedra (2D in triphylite and 1D in alluaudite), their 3D heteropolyhedral frameworks contain open channels elongated in one direction (Figure 9).

The first alluaudite analog, $\mathrm{Na}_{2}\left(\mathrm{Fe}^{3+}{ }_{0.5} \mathrm{Fe}^{2+}{ }_{0.5}\right)_{2} \mathrm{Fe}^{2+}\left(\mathrm{PO}_{4}\right)_{3}$, was obtained in the laboratory under hydrothermal conditions in 1977 [79], and analysis of its crystal structure revealed the new cation site on the twofold axis, populated by Na atoms. Synthetic materials with the alluaudite-type compounds are being actively studied today. The alluaudite-type structure provides not only fast transport of alkali ions (both $\mathrm{Li}^{+}$and $\mathrm{Na}^{+}$) but also allows for substantial variations in the chemical composition (from $\mathrm{Na}_{2} M_{2}\left(\mathrm{SO}_{4}\right)_{3}$ to $\left.\mathrm{Na}_{2} M_{3}\left(\mathrm{PO}_{4}\right)_{3}, M=\mathrm{Fe}, \mathrm{Mn}\right)$ through substitutions in the anionic and cationic positions. 
The most famous representative, $\mathrm{Na}_{2} \mathrm{Fe}_{2}\left(\mathrm{SO}_{4}\right)_{3}$, delivers a reversible capacity of $100 \mathrm{mAh} \cdot \mathrm{g}^{-1}(85 \%$ of the theoretical one) with the working potential located at $3.8 \mathrm{~V}$ (versus $\mathrm{Na} / \mathrm{Na}^{+}$), offering excellent rate kinetics and cycling stability [80]. However, its application is limited by the chemical instability (air sensitivity) and difficult preparation. By contrast, phosphate alluaudite-type materials can be easily synthesized using solid-state reaction or hydrothermal methods and have high chemical stability but demonstrate poorer electrochemical performance. $\mathrm{Na}_{2} \mathrm{Mn}_{2} \mathrm{~V}\left(\mathrm{PO}_{4}\right)_{3}$ exhibits electrochemical activity at an average voltage of $3.5 \mathrm{~V}\left(\mathrm{vs} . \mathrm{Na} / \mathrm{Na}^{+}\right.$), associated with the combination of $\mathrm{Mn}^{2+} / \mathrm{Mn}^{3+}$ and $\mathrm{V}^{3+} / \mathrm{V}^{4+}$ redox couples; the discharge capacity of $97 \mathrm{mAh} \cdot \mathrm{g}^{-1}$ corresponds to $89 \%$ of the theoretical one and fades quickly at different current rates [81]. The electrochemical properties of the Li-containing "alluaudites" $\mathrm{Li}_{0.5} \mathrm{Na}_{0.5} \mathrm{MnFe}_{2}\left(\mathrm{PO}_{4}\right)_{3}$ and $\mathrm{Li}_{0.75} \mathrm{Na}_{0.25} \mathrm{MnFe}_{2}\left(\mathrm{PO}_{4}\right)_{3}$ as positive electrodes in Li-cells were also studied: at an average potential of $2.7 \mathrm{~V}$, they demonstrated reversible insertion of 0.7 and $1.3 \mathrm{Li}^{+}$, respectively; these values are smaller than $1.7 \mathrm{Li}^{+}$intercalated into the non-lithiated $\mathrm{NaMnFe}_{2}\left(\mathrm{PO}_{4}\right)_{3}[82]$.

a)

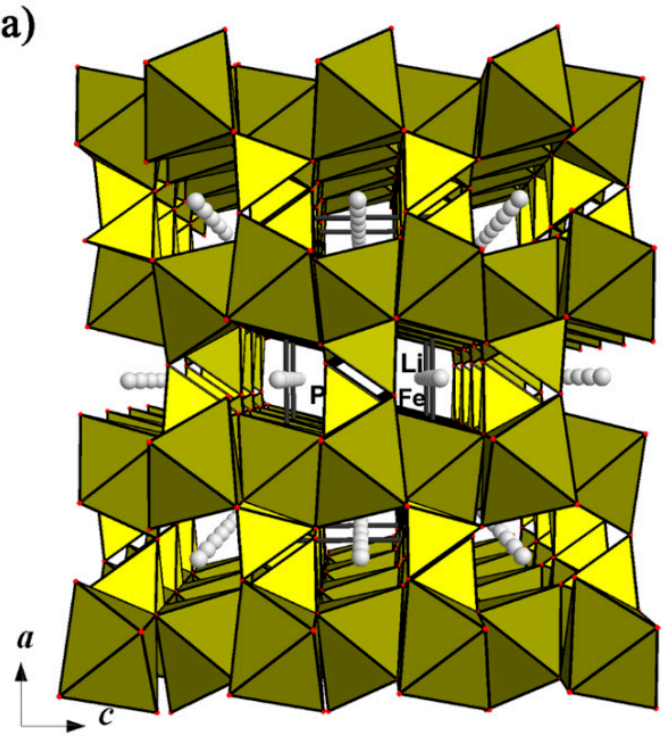

b)

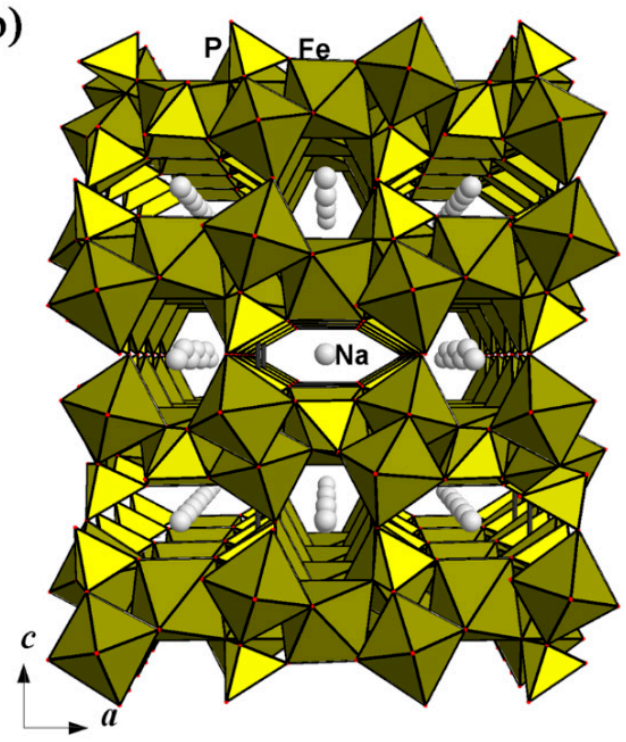

Figure 9. Crystal structures of triphylite, $\mathrm{LiFe}^{2+} \mathrm{PO}_{4}(\mathbf{a})$ and ferroalluaudite, $\mathrm{Na}_{2} \mathrm{Fe}^{3+} \mathrm{Fe}^{2+}{ }_{2}\left(\mathrm{PO}_{4}\right)_{3}(\mathbf{b})$ in an axonometric projection.

The mineral wyllieite with the ideal formula $\mathrm{Na}_{2} \mathrm{Fe}^{2+}{ }_{2} \mathrm{Al}\left(\mathrm{PO}_{4}\right)_{3}$ was firstly described in [83] as a primary crystallized phase in pegmatites. Later, this type of wyllieite received the name ferrowyllieite [84] and the real wyllieite occurs as a $\mathrm{Mn}^{2}+$ variety, namely $\mathrm{Na}_{2} \mathrm{Mn}^{2+} \mathrm{Fe}^{2+} \mathrm{Al}\left(\mathrm{PO}_{4}\right)_{3}$. Its crystal structure has been interpreted as very close to that of alluaudite, $\mathrm{Na}_{2} \mathrm{Mn}^{2+}\left(\mathrm{Fe}^{2+} \mathrm{Fe}^{3+}\right)\left[\mathrm{PO}_{4}\right]_{3}$. The main crystallographic difference between alluaudite and wyllieite having similar parameters of monoclinic unit cells is related to the type of Bravais lattices: the space group $P 2_{1} / n\left(P 2_{1} / c\right)$ typical for wyllieite is a subgroup of $C 2 / c(I 2 / a)$ of alluaudite. The space group reduction results from ordering over equivalent positions in the alluaudite structure type. The chains of edge sharing octahedra are traditionally considered as a basic fragment of the wyllieite and alluaudite structures. The way of cation distribution in the octahedral sites within these chains causes the formation of the first or the second structure type. The central $M(1)$ octahedron in the triplet of edge sharing polyhedra in both structures is usually occupied by $M^{2+}$ cations. The terminal $M(2)$ position, which is jointly occupied by $M^{2+}$ and $M^{3+}$ cations in alluaudite, splits into $M(2 \mathrm{a})$ and $M(2 \mathrm{~b})$ in wyllieite, with $M(2 \mathrm{~b})$ filled mainly by $M^{3+}$ cations(Figure 10a). In most crystal structures of the wyllieite mineral group, which counts seven members, this terminal position contains $\mathrm{Al}^{3+}$ and $\mathrm{Fe}^{3+}$ cations, with only one exception, that of fupingqiuite, $\left(\mathrm{Na}, \mathrm{Mn}^{2+}, \square\right)_{2} \mathrm{Mn}^{2+}{ }_{2} \mathrm{Fe}^{3+}\left(\mathrm{PO}_{4}\right)_{3}$, where it is fully populated by $\mathrm{Fe}^{3+}$ cations [85]. 
a)

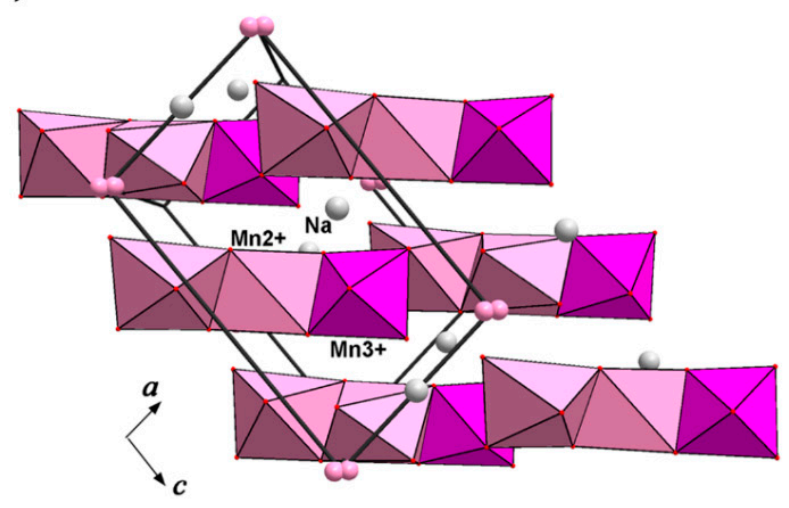

b)

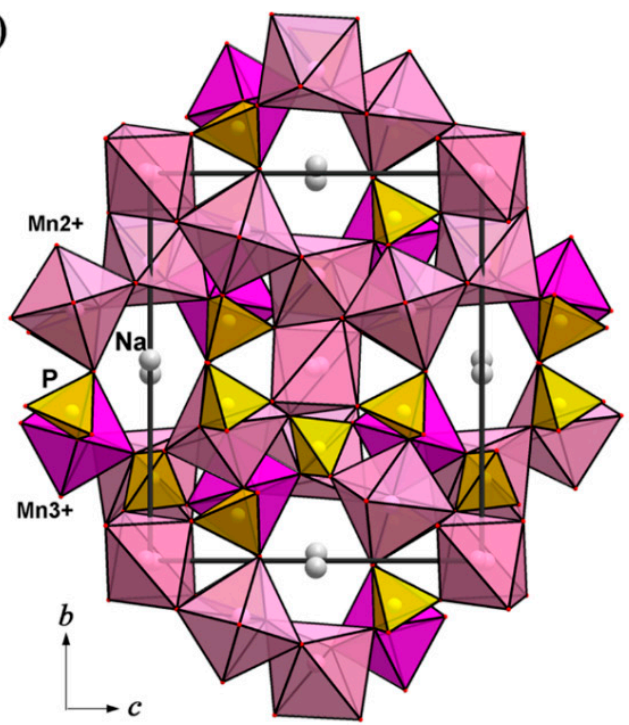

Figure 10. Chains along the $\{201\}$ built from $\mathrm{Mn}^{2+} \mathrm{O}_{6}$ (light pink) and $\mathrm{Mn}^{3+} \mathrm{O}_{6}$ (bright pink) octahedra (a) in the crystal structure of synthetic wyllieite, $\mathrm{NaMn}^{2+}{ }_{2.5} \mathrm{Mn}^{3+}\left(\mathrm{PO}_{4}\right)_{3}$ (view from the $\{100\}$ direction) (b).

A synthetic member in the wyllieite group with an ideal formula of $\mathrm{NaMn}^{2+}{ }_{2.5} \mathrm{Mn}^{3+}\left(\mathrm{PO}_{4}\right)_{3}$ was obtained under hydrothermal conditions. It is a new variety containing exclusively $\mathrm{Mn}$ atoms, besides $\mathrm{Na}^{+}$as alkaline cations. Triplets of edge sharing $\mathrm{Mn}(2)-\mathrm{Mn}(1)-\mathrm{Mn}(3)$ octahedra form chains parallel to the $\{210\}$ direction. These chains are linked by $\mathrm{Mn}(4)$ polyhedra to form an octahedral framework. The $\mathrm{PO}_{4}$ tetrahedra strengthen the framework by sharing all vertices with Mn octahedra. Na atoms occupy interstices of the structure $(\mathrm{Na}(2))$ and channels parallel to the $a$ axis $(\mathrm{Na}(1))$ (Figure 10). The accommodation of $\mathrm{Mn}(4)$ atoms in the structure leads to the transformation of the octahedral layer motif to that of a framework in synthetic Mn-wyllieite [86]. Unlike the minerals of the wyllieite group, the $\mathrm{NaMn}^{2+}{ }_{2.5} \mathrm{Mn}^{3+}\left(\mathrm{PO}_{4}\right)_{3}$ contains $\mathrm{Mn}^{3+}$ cations in the position usually occupied by $\mathrm{Al}$ (or $\mathrm{Fe}^{3+}$ ). As can be seen from Figure 10, the wyllieite crystal structure allows the migration of $\mathrm{Na}^{+}$ions through the open channels. The theoretical capacity value of $\mathrm{NaMn}^{2+}{ }_{2.5} \mathrm{Mn}^{3+}\left(\mathrm{PO}_{4}\right)_{3}$ is calculated to be $107 \mathrm{mAh} \cdot \mathrm{g}^{-1}$ if processes related to the deintercalation of $\mathrm{Na}^{+}$as well as the insertion of additional sodium into the structure are considered. The relatively low capacity might be compensated by a high potential associated with the $\mathrm{Mn}^{2+} / \mathrm{Mn}^{3+}$ redox couple, thus making this material quite interesting for further exploration.

There are two synthetic arsenate representatives of the wyllieite family, to our knowledge, $\mathrm{Ag}_{1.09} \mathrm{Mn}_{3.46}\left(\mathrm{AsO}_{4}\right)_{3}$ [87] and $\mathrm{Na}_{1.25} \mathrm{Co}^{2+}{ }_{2.187} \mathrm{Al}_{1.125}\left(\mathrm{AsO}_{4}\right)_{3}$ [88], obtained by solid state reaction. The crystal structure of the second compound with an ideal formula of $\mathrm{NaCo}^{2+}{ }_{2.5} \mathrm{Al}^{3+}\left(\mathrm{AsO}_{4}\right)_{3}$ is based on a $3 \mathrm{D}$ anionic framework built by $(\mathrm{Al} / \mathrm{Co}) \mathrm{O}_{6}$ octahedra and $\mathrm{AsO}_{4}$ tetrahedra, with $\mathrm{Na}^{+}$cations in channels. According to Marzouki et al. [88], the wyllieite-type arsenate crystal structure encloses an additional new $\mathrm{Na}^{+}$site as compared to other members of the family. The modeling of pathways for the $\mathrm{Na}^{+}$ migration through the anionic framework demonstrated that only the sodium called Na1 can diffuse through an infinite 1D pathway along the $\{100\}$ direction. Considering the high activation energy and rather low theoretical capacity of this synthetic arsenate $\left(87 \mathrm{mAh} \cdot \mathrm{g}^{-1}\right)$, and more importantly, the environmental impact, further investigation of these compounds as electrode materials for NIBs is not feasible.

4.2.3. Minerals with Two Sorts of Complex Anions: Sidorenkite, $\mathrm{Na}_{3} \mathrm{Mn}\left(\mathrm{PO}_{4}\right)\left(\mathrm{CO}_{3}\right)$ and Bonshtedtite, $\mathrm{Na}_{3} \mathrm{Fe}\left(\mathrm{PO}_{4}\right)\left(\mathrm{CO}_{3}\right)$

Sidorenkite and bonshtedtite are members of the bradleyite mineral group, which unites phosphate-carbonates with the general formula $\mathrm{Na}_{3} \mathrm{M}\left(\mathrm{PO}_{4}\right)\left(\mathrm{CO}_{3}\right)$. Sidorenkite, $\mathrm{Na} \mathrm{Mn}\left(\mathrm{PO}_{4}\right)\left(\mathrm{CO}_{3}\right)$, and its iron analogue bonshtedtite, $\mathrm{Na}_{3} \mathrm{Fe}\left(\mathrm{PO}_{4}\right)\left(\mathrm{CO}_{3}\right)$, are low-temperature hydrothermal minerals 
found in the highly alkaline hydrothermalites of the Khibiny massif, Kola Peninsula [89,90]. The minerals' crystal structures were solved and refined by [91] and [92]. The $\mathrm{MO}_{6}$ octahedra and $\mathrm{PO}_{4}$ tetrahedra share oxygen vertices to form layers parallel to the $y z$ plane of monoclinic (pseudo orthorhombic) structures. On the outside, along the $a$ axis, these layers are inlaid with $\mathrm{CO}_{3}$ groups sharing an edge with $M$-centered octahedra (Figure 11).

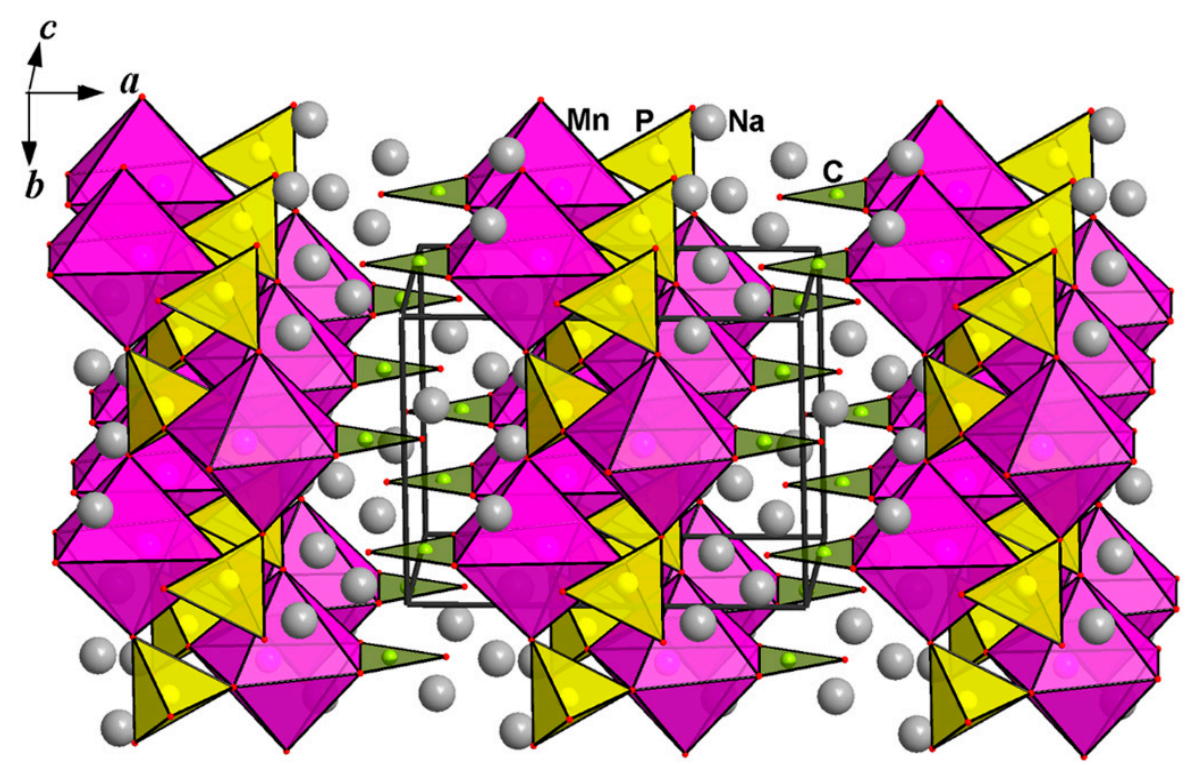

Figure 11. Crystal structure of sidorenkite, $\mathrm{Na}_{3} \mathrm{Mn}\left(\mathrm{PO}_{4}\right)\left(\mathrm{CO}_{3}\right)$, in an axonometric projection.

Investigation of carbonate-phosphates as candidates for NIB electrode materials was initiated by ab initio computations, which predicted good intercalation characteristics of sidorenkite with the theoretical capacity of $191 \mathrm{mAh} \cdot \mathrm{g}^{-1}$, owing to its capability to deliver the two-electron transfer via $\mathrm{Mn}^{2+} / \mathrm{Mn}^{3+}$ and $\mathrm{Mn}^{3+} / \mathrm{Mn}^{4+}$ redox reactions [93]. A series of carbonate-phosphates, $\mathrm{Na}_{3} \mathrm{M}\left(\mathrm{PO}_{4}\right)\left(\mathrm{CO}_{3}\right)$ $(\mathrm{M}=\mathrm{Mg}, \mathrm{Mn}, \mathrm{Fe}, \mathrm{Co}, \mathrm{Ni}, \mathrm{Cu}, \mathrm{Sr})$, were synthesized hydrothermally [94]. It was found that two Na-ions are extracted from $\mathrm{Na}_{3} \mathrm{Mn}\left(\mathrm{PO}_{4}\right)\left(\mathrm{CO}_{3}\right)$, resulting in a high initial charge capacity $\left(\sim 200 \mathrm{mAh} \cdot \mathrm{g}^{-1}\right)$; however, the sample showed a relatively large irreversible capacity $\left(\sim 75 \mathrm{mAh} \cdot \mathrm{g}^{-1}\right)$ at the initial discharge. At a slow rate, it delivered a stable capacity of over $125 \mathrm{mAh} \cdot \mathrm{g}^{-1}$ at an average potential of $3.2 \mathrm{~V}$ (vs. $\mathrm{Na} / \mathrm{Na}^{+}$) through a solid-solution-type structural evolution.

$\mathrm{Na}_{3} \mathrm{Mn}\left(\mathrm{PO}_{4}\right)\left(\mathrm{CO}_{3}\right)$ electrode materials with improved reversible capacity were reported $[95,96]$. Thus, Hassanzadeh et al. obtained a $\mathrm{Na}_{3} \mathrm{Mn}\left(\mathrm{PO}_{4}\right)\left(\mathrm{CO}_{3}\right) / \mathrm{rGO}$ (reduced Graphene Oxide) nanocomposite with a reversible capacity of over $156 \mathrm{mAh} \cdot \mathrm{g}^{-1}$; however, the electrode exhibited high charge/discharge polarization with fast capacity degradation.

A special hydrothermal technique was applied to obtain bonshtedtite, $\mathrm{Na} \mathrm{Fe}_{3} \mathrm{Fe}\left(\mathrm{PO}_{4}\right)\left(\mathrm{CO}_{3}\right)$, analogue with nanoplatelet morphology. The new material showed an initial capacity of $120 \mathrm{mAh} \cdot \mathrm{g}^{-1}$ and demonstrated a stable capacity value of $96 \mathrm{mAh} \cdot \mathrm{g}^{-1}$ after 50 cycles [97].

\subsubsection{Phosphate Cathode Materials, Structurally Derived from Mineral Natisite, $\mathrm{Na}_{2} \mathrm{TiSiO}_{5}$}

Natisite, $\mathrm{Na}_{2} \mathrm{TiSiO}_{5}$, is a typical mineral of ultra-agpaitic pegmatites and hydrothermalites; it can be treated as an indicator of highly alkaline conditions. It was found and described in [98]. The crystal structure of natisite contains layers of $\mathrm{TiO}_{5}$ hemi-octahedra (the sixth Ti-O distance is about $3.393 \AA$ ) and $\mathrm{SiO}_{4}$ tetrahedra with $\mathrm{Na}$ atoms between the layers [99]. The layer is a four-connected net (a square with alternating corner-sharing Ti pyramids and Si tetrahedra) (Figure 12a). Each Ti hemi-octahedron shares its four equatorial $\mathrm{O}$ atoms with four different $\mathrm{SiO}_{4}$ groups; thus, forming an essential building block (Figure 12b). 
a)

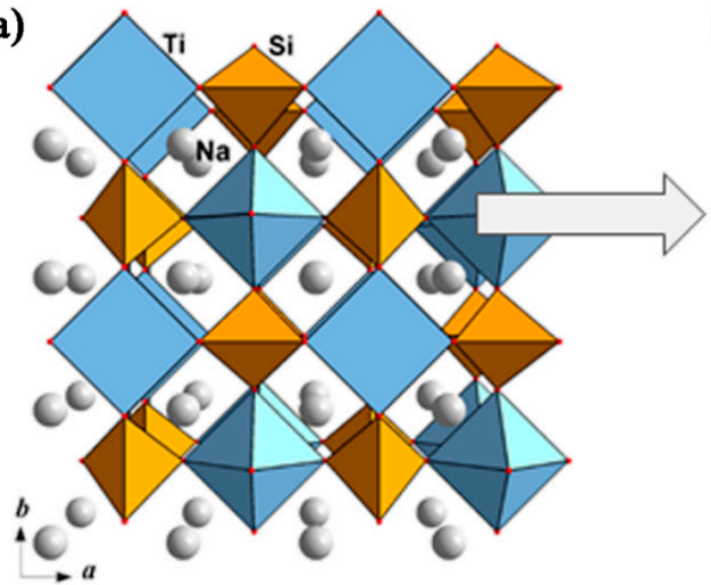

b)

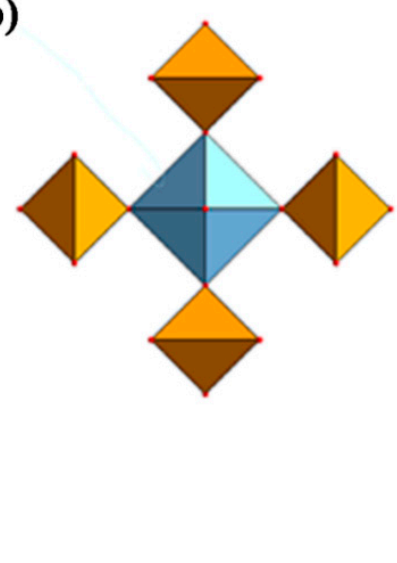

Figure 12. Crystal structure of the tetragonal natisite, $\mathrm{Na}_{2} \mathrm{TiSiO}_{5}$, in basic $x y$ projection (a) and the block of the central $\mathrm{TiO}_{5}$ semi-octahedron sharing vertices with four $\mathrm{SiO}_{4}$ tetrahedra (b).

A number of phosphate crystal structures can be considered as derivatives of the mineral natisite, $\mathrm{Na}_{2} \mathrm{TiSiO}_{5}$, for example, $\mathrm{Na}_{3}\left[\mathrm{Fe}_{2}(\mathrm{OH})_{2} \mathrm{~F}\left(\mathrm{PO}_{4}\right)_{2}\right]$ [100], $\mathrm{Na}_{3}\left[\mathrm{Cr}_{2} \mathrm{~F}_{3}\left(\mathrm{PO}_{4}\right)_{2}\right]$ [101], $\mathrm{Na}_{3}\left[\mathrm{Fe}_{2} \mathrm{~F}_{3}\left(\mathrm{PO}_{4}\right)_{2}\right]$ [102], $\mathrm{Na}_{3}\left[\mathrm{Al}_{2} \mathrm{~F}_{3}\left(\mathrm{PO}_{4}\right)_{2}\right]$ [103], and $\mathrm{Na}_{3}\left[\mathrm{~V}_{2} \mathrm{O}_{2} \mathrm{~F}\left(\mathrm{PO}_{4}\right)_{2}\right]$ [104]. They differ from natisite mainly by the degree of association of the mixed anionic substructure (layer or paraframework) and show symmetry relations of the "group-subgroup" type. The incorporation of $\mathrm{F}$ atoms in the interlayer space (with the simultaneous substitution of $\mathrm{Si}$ in tetrahedra for $\mathrm{P}$, and $\mathrm{Ti}$ in octahedra for $\mathrm{V}$ ) is accompanied by a transformation of $2 \mathrm{D}$ nets to $3 \mathrm{D}$ framework (layers connect along $c$ trough common F-vertices of neighboring octahedra) in $\mathrm{Na}_{1.5}\left\{\mathrm{VOF}_{0.5}\left[\mathrm{PO}_{4}\right]\right\}$. Thus, the crystal structure of the V-containing member of the series, $\mathrm{Na}_{3}\left[\mathrm{~V}_{2} \mathrm{O}_{2} \mathrm{~F}\left(\mathrm{PO}_{4}\right)_{2}\right]$, is formed by layers of alternating $\left(\mathrm{VO}_{5} \mathrm{~F}\right)$ octahedra and $\left(\mathrm{PO}_{4}\right)$ tetrahedra sharing $\mathrm{O}$ vertices. These layers are loosely interconnected along the $\mathrm{c}$ axis over the F-ligands, while the vanadyl $\mathrm{O}$ atoms remain terminal, and $\mathrm{Na}^{+}$cations are disordered in the framework channels (Figure 13a). Strongly distorted $\left(\mathrm{VO}_{5} \mathrm{~F}\right)$ octahedra with one short distance, $\mathrm{V}-\mathrm{O}$ of $1.625 \AA$, characterizing the vanadyl group, correspond to rather regular $\mathrm{MO}_{4} \mathrm{~F}_{2}(\mathrm{Fe}, \mathrm{Al}$, and $\mathrm{Cr})$ octahedra in other phosphate analogs. Figure 13b demonstrates the distortion of the octahedra in the structures under discussion.

a)

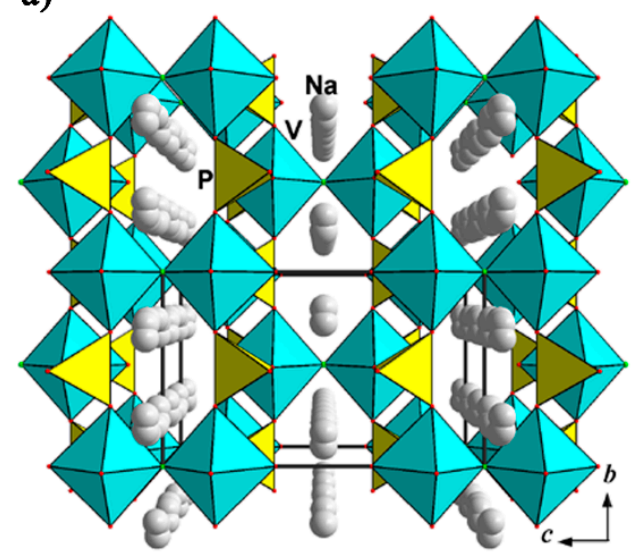

b)

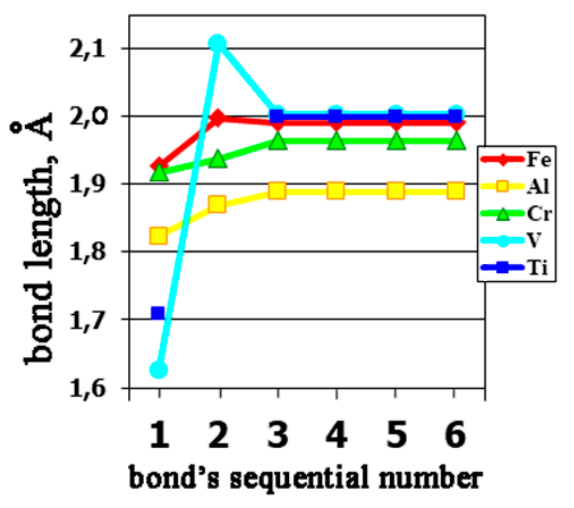

Figure 13. Crystal structure of $\mathrm{Na}_{3} \mathrm{~V}_{2} \mathrm{O}_{2} \mathrm{~F}\left(\mathrm{PO}_{4}\right)$ in axonometric projection; spheres: disordered $\mathrm{Na}$ atoms (a), and $M$-centered polyhedra distortion (b).

Sodium-rich natisite-related Fe- and V-bearing fluoride phosphates, $\mathrm{Na}_{3} \mathrm{~V}_{2} \mathrm{O}_{2}\left(\mathrm{PO}_{4}\right)_{2} \mathrm{~F}$ and $\mathrm{Na}_{3} \mathrm{~V}_{2}\left(\mathrm{PO}_{4}\right)_{2} \mathrm{~F}_{3}$, are isostructural and form the $\mathrm{Na}_{3} \mathrm{~V}_{2} \mathrm{O}_{2 x}\left(\mathrm{PO}_{4}\right)_{2} \mathrm{~F}_{3-2 x}$ solid solution $(0 \leq x \leq 1)$. They have drawn much attention as promising cathode materials for sodium-ion batteries: fluorine 
introduction effectively increases the voltage due to enhancement of the ionicity of the anionic framework; the reversible extraction of two $\mathrm{Na}^{+}$corresponds to a theoretical capacity of $128 \mathrm{mAh} \cdot \mathrm{g}^{-1}$. Although these compounds are active in both Li- and Na-cells, the electrochemical properties in the latter are the most attractive. Thus, the $\mathrm{Na}_{3} \mathrm{~V}_{2} \mathrm{O}_{2 x}\left(\mathrm{PO}_{4}\right)_{2} \mathrm{~F}_{3-2 x}$ materials were shown to demonstrate outstanding performance in the Na-cell, providing high energy densities $\left(>500 \mathrm{~W} \mathrm{~h} \mathrm{~kg}^{-1}\right)$ which are competitive with that delivered by $\mathrm{LiFePO}_{4}$ in LIBs [105,106]. According to [106], the reversible sodium de/intercalation in $\mathrm{Na}_{3} \mathrm{~V}_{2} \mathrm{O}_{1.6}\left(\mathrm{PO}_{4}\right)_{2} \mathrm{~F}_{1.4}$ taking place at 3.65 and $4.02 \mathrm{~V}\left(\mathrm{vs} . \mathrm{Na}^{+} / \mathrm{Na}\right)$ is characterized by small volume changes (less than $3 \%$ ) and low activation barriers for Na diffusion. It results in remarkable cycling stability and excellent rate capability (with capacity of more than $100 \mathrm{mAh} \cdot \mathrm{g}^{-1}$ delivered at a 3 min charge/discharge rate). Comprehensive investigation of $\mathrm{Na}_{3} \mathrm{~V}_{2} \mathrm{O}_{2 x}\left(\mathrm{PO}_{4}\right)_{2} \mathrm{~F}_{3-2 x}$ revealed that the initial composition and thus the vanadium oxidation state have a major impact on electrochemical performance, with the de/intercalation mechanism evolving from two-phase behavior with two voltage plateaus for $\mathrm{x}=0$ to solid-solution type reactions with an "S-shape" for the two voltage domains for $\mathrm{x}=1$ [107].

4.2.5. Phosphate Analogues of Katiarsite, $\mathrm{KTiOAsO}_{4}$ and Yurgensonite, $\mathrm{K}_{2} \mathrm{SnTiO}_{2}\left(\mathrm{AsO}_{4}\right)_{2}$ ， as Successive Electrode Materials for K-Ion Batteries

Two arsenate minerals, katiarsite, $\mathrm{KTiOAsO}_{4}$, and yurgensonite, $\mathrm{K}_{2} \mathrm{SnTiO}_{2}\left(\mathrm{AsO}_{4}\right)_{2}$, were discovered recently in the volcanic fumaroles' environment [108]. According to [109], yurgensonite, $\mathrm{K}_{2} \mathrm{SnTiO}_{2}\left(\mathrm{AsO}_{4}\right)_{2}$, is the $\mathrm{Sn} /$ Ti-ordered analogue of katiarsite.

As it happens, their many synthetic structural analogues, collectively known as KTP (short for $\mathrm{KTiPO}_{5}$ ), were obtained, and studied more than 35 years ago. They are described by the common formula $A M\left[\mathrm{XO}_{4}\right] \mathrm{Z}$, where $A=\mathrm{K}, \mathrm{Tl}, \mathrm{Rb}, \mathrm{Cs}, \mathrm{Ag}$, and $\mathrm{NH}_{4} ; M=\mathrm{Ti}, \mathrm{Fe}, \mathrm{Al}, \mathrm{Cr}, \mathrm{Ge}, \mathrm{Ga}, \mathrm{Sb}, \mathrm{Sn}, \mathrm{Ta}, \mathrm{Zr}$, and $\mathrm{V} ; \mathrm{X}=\mathrm{P}, \mathrm{As}, \mathrm{Si}$, and $\mathrm{Ge}$; and $\mathrm{Z}=\mathrm{O}$ and $\mathrm{F}$. These compounds, being of interest as nonlinear-optical, ferroelectric, and superionic materials, recently began to be studied as possible candidates for batteries' cathodes. A mixed-type anionic framework is built by chains of $M$-centered octahedra sharing cis- and trans-vertices and $\mathrm{XO}_{4}$ tetrahedra, linking these chains in a 3D construction through vertex-bridging contacts. The voids of the framework are filled by large single-charge cations (Figure 14).

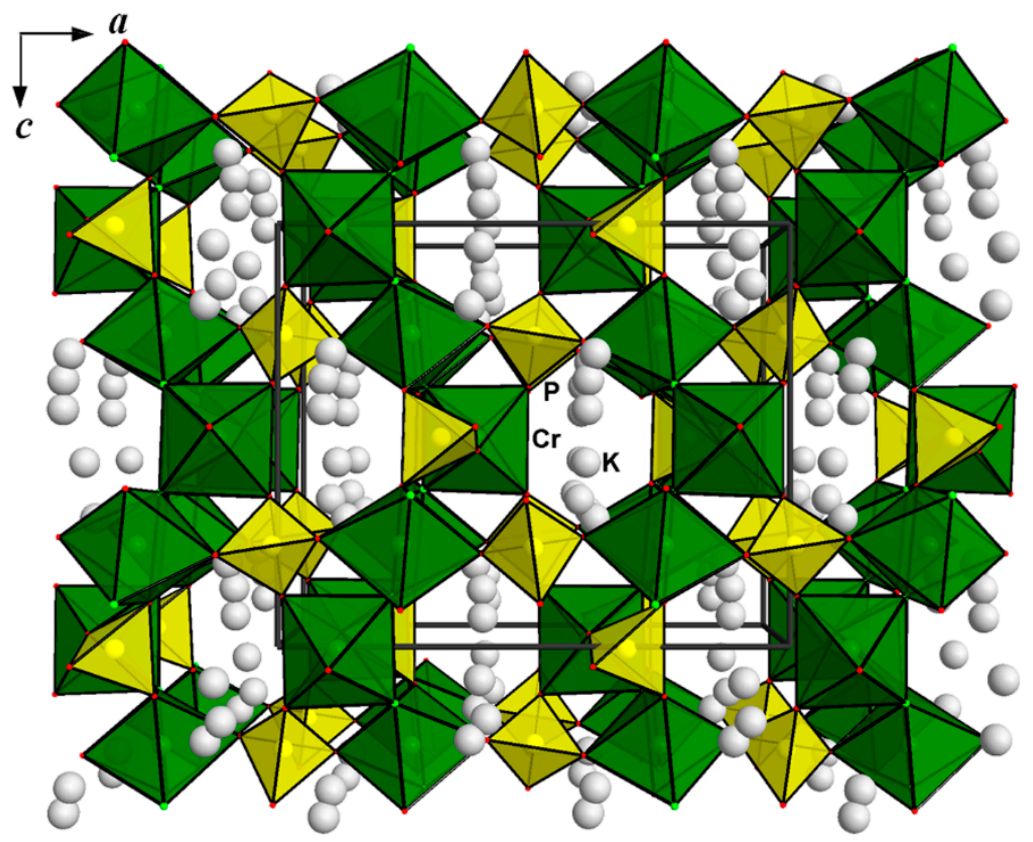

Figure 14. Polyhedral representation of the $\mathrm{KTP}$ (short for $\mathrm{KTiPO}_{5}$ ) structure type shown for the $\mathrm{K}(\mathrm{Ti}, \mathrm{Cr})\left[\mathrm{PO}_{4}\right](\mathrm{O}, \mathrm{F})$ solid solution. 
Known as a good ionic conductor, this type of compounds has attracted attention as a possible material for metal-ion batteries. For the first time, unique electrochemical properties of $\mathrm{KFeSO}_{4} \mathrm{~F}$ cathode material with KTP structure were discovered by Tarascon's group [110]. Later, the V-bearing phosphates, $\mathrm{KVPO}_{4} \mathrm{~F}$ and $\mathrm{KVOPO}_{4}$, were found to demonstrate attractive electrochemical performance. Thus, the $\mathrm{K}_{0.15} \mathrm{VPO}_{4} \mathrm{~F}$ electrode ("VPO4F") obtained from $\mathrm{KVPO}_{4} \mathrm{~F}$ through electrochemical oxidation exhibited a reversible uptake of $0.7 \mathrm{Li}$ per formula unit at an average voltage of $\sim 4 \mathrm{~V} v \mathrm{vs}$. $\mathrm{Li} / \mathrm{Li}^{+}$ and excellent rate capability, maintaining more than $50 \%$ of the theoretical capacity $\left(>80 \mathrm{mAh} \cdot \mathrm{g}^{-1}\right)$ at 90 second charge-discharge rate [111]. Moreover, the $\mathrm{KTP}$-related " $\mathrm{VPO}_{4} \mathrm{~F}^{\text {" framework sustains }}$ reversible extraction/insertion of four alkali ions $\left(\mathrm{Li}^{+}, \mathrm{Na}^{+}, \mathrm{K}^{+}\right.$, and even $\left.\mathrm{Rb}^{+}\right)$with fast ionic mobility and high diffusion coefficients [112]. Solid-state transport properties of this framework were found to be very different for these alkali cations: the lowest values of the apparent diffusion coefficient were observed for lithium ions, while the diffusivity of $\mathrm{K}^{+}$was shown to be the highest in the series. These findings confirmed the attractiveness of employing this material in sodium-ion and especially potassium-ion batteries [111].

The electrochemical performance of $\mathrm{KVPO}_{4} \mathrm{~F}$ and $\mathrm{KVOPO}_{4}$ in $\mathrm{K}$-cells was investigated [113,114]. These materials were reported to deliver reversible capacities of 92 and $84 \mathrm{mAh} \cdot \mathrm{g}^{-1}$, respectively, with very good rate performance attributed to the open framework of the KTP type crystal structure. The average working voltages attributed to the $\mathrm{V}^{3+} / \mathrm{V}^{4+}$ and $\mathrm{V}^{4+} / \mathrm{V}^{5+}$ redox couples were found to be very close: at $4.02 \mathrm{~V}$ for $\mathrm{KVPO}_{4} \mathrm{~F}$ and $3.95 \mathrm{~V}$ for $\mathrm{KVOPO}_{4}$ [113].

The reversible $\mathrm{K}$ extraction/insertion from $\mathrm{KVPO}_{4} \mathrm{~F}$ was confirmed by ex situ X-ray diffraction characterization and $a b$ initio calculations, unveiling the formation of intermediate compounds at $\mathrm{x}=0.75,0.625$, and 0.5 [114]. The authors also explained the effect of the F/O ratio on the electrochemical properties of $\mathrm{KVPO}_{4+\mathrm{x}} \mathrm{F}_{1-\mathrm{x}}$, suggesting that the oxygenation of $\mathrm{KVPO}_{4} \mathrm{~F}$ resulted in a more disordered structure around the $\mathrm{K}$ and $\mathrm{V}$ sites and in a smooth voltage profile. In addition, they claimed that oxygen substitution for fluorine in $\mathrm{KVPO}_{4} \mathrm{~F}$ decreases the operating voltage because of a reduced inductive effect in the compound with lower F-content.

Recently, a titanium-based electrode material, $\mathrm{KTiPO}_{4} \mathrm{~F}$, exhibiting a superior electrode potential of $3.6 \mathrm{~V}$ in a potassium-ion cell has been reported. $\mathrm{KTiPO}_{4} \mathrm{~F}$ demonstrates a complex charge-discharge behavior characterized by three distinct reversible processes at $2.7,3.1$, and $3.6 \mathrm{~V}$ (vs. $\mathrm{K} / \mathrm{K}^{+}$), and all three processes display plateau-like voltage profiles indicating a two-phase transformation mechanism. Carbon-coated $\mathrm{KTiPO}_{4} \mathrm{~F}$ delivered a capacity of $94 \mathrm{mAh} \cdot \mathrm{g}^{-1}$ (uptake of $0.8 \mathrm{~K}$ ) at a rate of C/20 with high cycling stability. The authors suggested that a combination of chemical (inductive effect) and structural (charge/vacancy ordering, electrostatics) peculiarities of the electrode material results in extraordinarily high potential for the $\mathrm{Ti}^{3+} / \mathrm{Ti}^{4+}$ redox activity, thus making it an attractive cathode material for K-ion batteries; before this finding, the $\mathrm{Ti}^{3+} / \mathrm{Ti}^{4+}$ redox couple was considered for anode materials [115].

\subsubsection{Arrojadite-Type Compounds}

Mineral arrojadite, first described in the late eighteenth century [116] as an unknown mineral "near triphylite" from the Nickel Plate pegmatite in South Dakota, was not structurally characterized until the 1980s. After a first publication devoted to the structural study of arrojadite [117], the crystal structures of this mineral of diverse composition from different pegmatites have been investigated. According to [118], arrojadite is normally found as unaltered and unleached species.

The basis of the crystal structure of arrojadite, $\mathrm{KNa}_{4} \mathrm{Ca}(\mathrm{Fe}, \mathrm{Mn})_{14} \mathrm{Al}\left(\mathrm{PO}_{4}\right)_{12}(\mathrm{OH}, \mathrm{F})_{2}$, presents a dense 3D framework built by Fe-, $\mathrm{Mn}$-, and Al-centered polyhedra sharing edges. $\mathrm{PO}_{4}$ tetrahedra strengthen the framework by sharing vertices and edges with octahedra and five-vertex polyhedra populated by transition metal atoms or Al. Different cations occupy positions in the framework voids or channels, where they are often statistically distributed, having static or dynamic disorder [119].

To the best of our knowledge, there is only one report regarding the synthetic analog of arrojadite obtained. Brown-black prismatic crystals up to $1 \mathrm{~mm}$ in size were synthesized under hydrothermal conditions at $\mathrm{T}=450{ }^{\circ} \mathrm{C}$ and $\mathrm{P}=1000 \mathrm{~atm}$ [120]. As noted in [118], the role of statistics in the 
distribution of atoms is unusually important in the structure of arrojadite, as confirmed by the structure of its synthetic analogue, with fourteen disordered cation and two disordered anion positions. A main difference between the mineral and its synthetic counterpart lies in the chemical composition. Thus, in synthetic arrojadite, $\mathrm{K}_{2} \mathrm{Na}_{5} \mathrm{Fe}^{2+}{ }_{14} \mathrm{Fe}^{3+}\left(\mathrm{PO}_{4}\right)_{12}(\mathrm{OH})_{2}$, the Fe atoms in a oxidation state of $3+$ correspond to the $\mathrm{Al}$ atoms that usually occur in the composition of mineral phases. The largest negatively charged channels are open along the $b$ axis through six-membered windows; they include $\mathrm{Na}^{+}$and $\mathrm{K}^{+}$cations. There are four such channels in the unit cell, parallel to each other (Figure 15). The theoretical capacity of $\mathrm{K}_{2} \mathrm{Na}_{5} \mathrm{Fe}^{2+}{ }_{14} \mathrm{Fe}^{3+}\left(\mathrm{PO}_{4}\right)_{12}(\mathrm{OH})_{2}$ is only $84 \mathrm{mAh} \cdot \mathrm{g}^{-1}$, since half of the transition metals are not involved in the redox process, in addition to the weight penalty of the large oxoanion part.

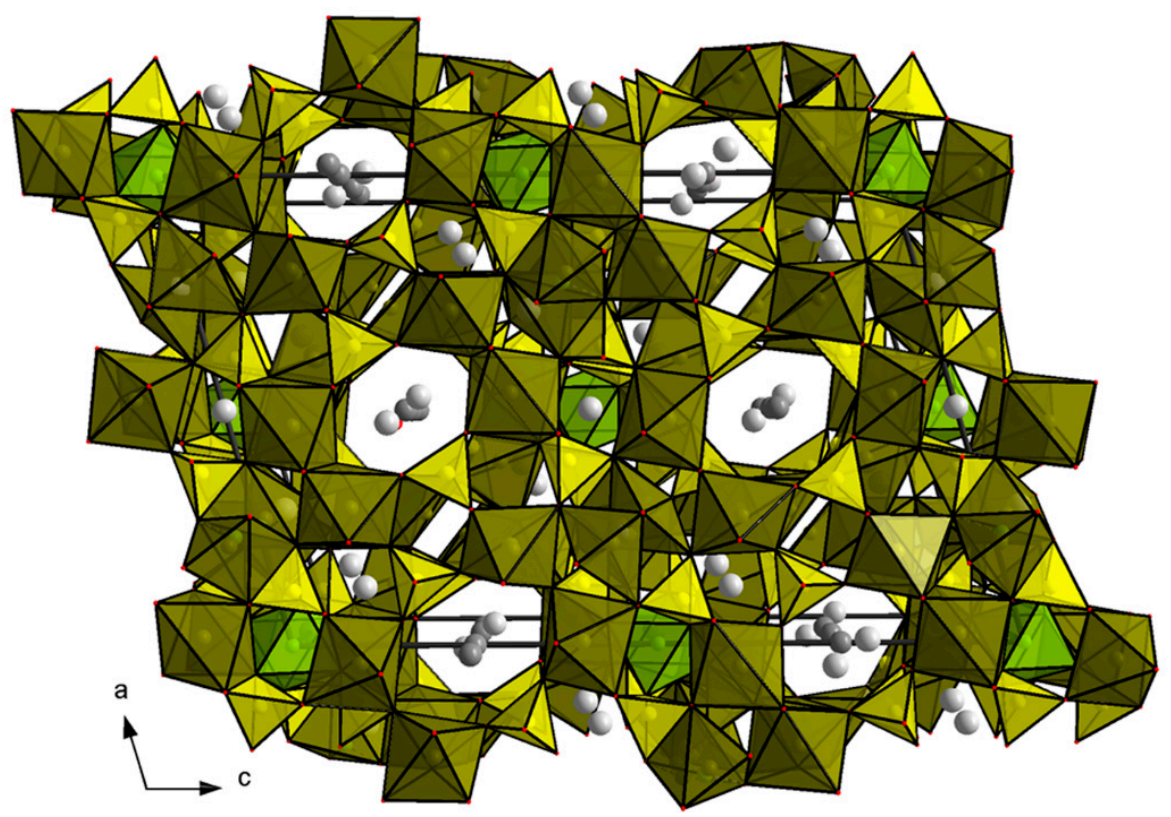

Figure 15. The arrojadite crystal structure of a synthetic $\mathrm{Fe}^{3+}$ variety exposed. Phosphate tetrahedra are shown in yellow, $\mathrm{Fe}^{3+}$-centered octahedra in light green, $\mathrm{Fe}^{2+}$-centered polyhedra in green, $\mathrm{Na}$ as light gray spheres, and $\mathrm{K}$ atoms as dark gray spheres.

The electrochemical activity of natural arrojadite $\mathrm{Na}_{3} \mathrm{~K}_{1.22} \mathrm{AlMn}_{6} \mathrm{Fe}_{8.35}\left(\mathrm{PO}_{4}\right)_{12}(\mathrm{OH})_{2}$ was investigated for the $\mathrm{Li}_{x} \mathrm{AlMn}_{6} \mathrm{Fe}_{8.35}\left(\mathrm{PO}_{4}\right)_{12}(\mathrm{OH})_{2}$ composition prepared by substitution of $\mathrm{Na}^{+}$and $\mathrm{K}^{+}$ions for $\mathrm{Li}^{+}$[121]. In a Li-cell, the obtained sample delivered quite low capacity, probably due to the improper morphology of the electrode material. The author reported high thermal and cycling stability of the arrojadite material assigned to its framework crystal structure. Because of their small theoretical capacity, arrojadite-based materials can hardly be used as commercial cathodes; however, the features of their crystal structure might inspire hope for new, stable objects [121].

\section{Conclusions}

The given examples of the successful usage of mineralogical and crystal chemical information concerning phosphates (Table 1 ) to create modern battery materials can be supplemented by lipscombite, $\left(\mathrm{Fe}^{2+}, \mathrm{Fe}^{3+}\right)_{3}\left(\mathrm{PO}_{4}\right)_{2}(\mathrm{OH}, \mathrm{O})_{2}$, its ordered polymorph barbosalite, $\mathrm{Fe}^{2+} \mathrm{Fe}^{3+}{ }_{2}\left(\mathrm{PO}_{4}\right)_{2}(\mathrm{OH})_{2}$, minerals of the triplite-zwieselite, $(\mathrm{Mn}, \mathrm{Fe})_{2}\left(\mathrm{PO}_{4}\right) \mathrm{F}$, and triploidite-wolfeite, $(\mathrm{Mn}, \mathrm{Fe})_{2}\left(\mathrm{PO}_{4}\right) \mathrm{OH}$ series, lithiophosphate, $\mathrm{Li}_{3} \mathrm{PO}_{4}$, and some others. In particular, we have highlighted above two candidates to test as possible cathode materials for Me-ion batteries: the wyllieite-like $\mathrm{NaMn}^{2+}{ }_{2.5} \mathrm{Mn}^{3+}\left(\mathrm{PO}_{4}\right)_{3}$ and the arrojadite $\mathrm{K}_{2} \mathrm{Na}_{5} \mathrm{Fe}^{2+}{ }_{14} \mathrm{Fe}^{3+}\left(\mathrm{PO}_{4}\right)_{12}(\mathrm{OH})_{2}$, along with their derivatives. Many recently discovered phosphate minerals may also stand as prototypes to create new battery electrode materials.

Although most current cathode materials for metal-ion batteries are phosphates, representatives of other mineral classes with complex anions, for example, silicates, sulfates, borates, and vanadates, 
might be considered in this respect; the above-discussed mineral natisite, $\mathrm{Na}_{2} \mathrm{TiSiO}_{5}$, is a good example. One more illustration may be given in connection with the rare minerals grandidierite, $\mathrm{MgAl}_{3}\left(\mathrm{SiO}_{4}\right)\left(\mathrm{BO}_{3}\right) \mathrm{O}_{2}$, and ominelite, $\mathrm{FeAl}_{3} \mathrm{O}_{2}\left(\mathrm{SiO}_{4}\right)\left(\mathrm{BO}_{3}\right)$. Synthetic fluoride phosphates with the common formula $A_{2} M\left(\mathrm{PO}_{4}\right) \mathrm{F}$, where $A=\mathrm{Li}, \mathrm{Na}$ and $\mathrm{M}=\mathrm{Ni}, \mathrm{Fe}, \mathrm{Co}, \mathrm{Mn}, \mathrm{Mg}$, extensively studied as promising cathodes for LIBs and NIBs (see, for instance one of the latest papers: [122]) are structural analogues of the mentioned natural silicate-borates [123].

Coming back to the problem of the search of novel materials for a battery cathode design, let us emphasize that data about mineral genesis contain important information on the conditions under which a particular structure was developed. The chemical compositions of mineral species indicate the types of atoms participating in their stable crystal structures, and the results of X-ray and neutron diffraction studies reveal the preferred positions for their population by definite ions. Subsequent topological analysis of crystal structures will facilitate identification of possible migration routes of ions and help to predict the electrochemical properties of compounds. Crystallographic and mineral databases provide useful information on phases with rigid framework structures, their chemical stability, and possible ion diffusion pathways within the framework. This suggests that mineral-like compounds, primarily phosphates and silicates, might be prototypes of novel electrode materials for metal-ion batteries. The widespread prevalence of silicates and phosphates in nature makes it possible, on the one hand, to obtain their synthetic analogues and, on the other hand, to guarantee the low cost and environmental safety of these materials.

Table 1. Composition and crystal characteristics of synthetic analogues of minerals, studied as cathode materials.

\begin{tabular}{|c|c|c|c|}
\hline Formula (Mineral Name) & Unit-Cell Parameters $a, b, c, \AA$ and $\alpha, \beta, \gamma_{r}^{\circ}$ & $\begin{array}{l}\text { Space Group, } V \AA^{3}, \\
\mathrm{~g} / \mathrm{cm}^{3}, Z\end{array}$ & Ref. \\
\hline \multicolumn{4}{|c|}{ 1. The olivine $(\mathrm{Fe}, \mathrm{Mg})_{2}\left(\mathrm{SiO}_{4}\right)$ Structure Type and Its Derivatives } \\
\hline \multicolumn{4}{|c|}{ Fe End Members } \\
\hline $\mathrm{LiFe}\left(\mathrm{PO}_{4}\right)$ (triphylite) & $a=10.332(4), b=6.010(5), c=4.787(4)$ & $\begin{array}{c}\text { Pnma, } 297.25 \\
3.53,4\end{array}$ & [124] \\
\hline $\mathrm{NaFe}\left(\mathrm{PO}_{4}\right)$ (karenwebberite) & $a=10.4063(6), b=6.2187(3), c=4.9469(3)$ & $\begin{array}{l}\text { Pnma, } 320.13 \\
3.61,4\end{array}$ & [53] \\
\hline $\mathrm{NaFe}\left(\mathrm{PO}_{4}\right)$ (marićite) & $a=9.001(8), b=6.874(3), c=5.052(4)$ & $\begin{array}{l}\text { Pnma, } 312.58 \\
3.69,4\end{array}$ & [125] \\
\hline $\mathrm{Fe}_{3}\left(\mathrm{PO}_{4}\right)_{2}$ (sarcopside) & $\begin{array}{c}a=10.450(11), b=6.033(6), c=4.782(5) \\
\gamma=90.96(8)\end{array}$ & $\begin{array}{c}P 112_{1} / a^{*}, 301.44 \\
3.94,2\end{array}$ & [126] \\
\hline $\mathrm{Fe}\left(\mathrm{PO}_{4}\right)$ (heterosite) & $a=9.839(1), b=5.809(3), c=4,776(1)$ & $\begin{array}{l}\text { Pnma, } 272.97 \\
3.67,4\end{array}$ & [127] \\
\hline $\begin{array}{c}\mathrm{NH}_{4} \mathrm{Fe}\left(\mathrm{PO}_{4}\right) \mathrm{HF} \\
\text { (Fe variety of niahite) }\end{array}$ & $a=8.958(2), b=5.649(1), c=4.811(1)$ & $\begin{array}{l}\text { Pnm } 2_{1}, 243.45 \\
2.58,2\end{array}$ & [37] \\
\hline \multicolumn{4}{|c|}{ Mn End Members } \\
\hline $\mathrm{LiMn}\left(\mathrm{PO}_{4}\right)$ (lithiophilite) & $a=10.46(3), b=6.10(2), c=4.744(10)$ & $\begin{array}{l}\text { Pnma, } 302.7 \\
3.44,4\end{array}$ & [128] \\
\hline $\mathrm{NaMn}\left(\mathrm{PO}_{4}\right)$ (natrophilite) & $a=10.523(5), b=6.312(3), c=4.987(2)$ & $\begin{array}{l}\text { Pnma, } 330.48 \\
\quad 3.47,4\end{array}$ & [52] \\
\hline $\begin{array}{c}\mathrm{NaMn}\left(\mathrm{PO}_{4}\right)(\mathrm{Mn} \text { analogue of } \\
\text { marićite })\end{array}$ & $a=9.0882(1), b=6.9041(1), c=5.1134(1)$ & $\begin{array}{l}\text { Pnma, } 320.84 \\
3.58,4\end{array}$ & [129] \\
\hline $\mathrm{Mn}\left(\mathrm{PO}_{4}\right)$ (purpurite) & $a=9.6237(7), b=5.9019(3), c=4.7711(3)$ & $\begin{array}{l}\text { Pnma, } 270.99 \\
3.67,4\end{array}$ & [130] \\
\hline $\begin{array}{l}\mathrm{NH}_{4} \mathrm{Mn}\left(\mathrm{PO}_{4}\right)\left(\mathrm{H}_{2} \mathrm{O}\right) \text { (niahite } \\
\text { centrosymmetric variety) }\end{array}$ & $a=17.5822(3), b=5.7310(1), c=4.9090(1)$ & $\begin{array}{l}\text { Pnma }, 494.65 \\
2.50,4\end{array}$ & [41] \\
\hline
\end{tabular}


Table 1. Cont

\begin{tabular}{|c|c|c|c|}
\hline Formula (Mineral Name) & Unit-Cell Parameters $a, b, c, \AA$ and $\alpha, \beta, \gamma^{\circ}$ & $\begin{array}{l}\text { Space Group, } V \AA^{3}, \\
\mathrm{~g} / \mathrm{cm}^{3}, Z\end{array}$ & Ref. \\
\hline \multicolumn{4}{|c|}{ 2. The Tavorite, $\mathrm{LiFe}\left(\mathrm{PO}_{4}\right)(\mathrm{OH}, \mathrm{F})$ Structure Type } \\
\hline $\mathrm{LiFe}\left(\mathrm{PO}_{4}\right)(\mathrm{OH})$ (tavorite) & $\begin{array}{c}a=5.3528(6), b=7.2896(7), c=5.1187(5) \\
\alpha=109.359(4), \beta=97.733(5), \gamma=106.359(5)\end{array}$ & $\begin{array}{l}P \overline{1}, 174.98 \\
3.22,2\end{array}$ & [49] \\
\hline $\mathrm{LiV}\left(\mathrm{PO}_{4}\right) \mathrm{F}$ (tavorite) & $\begin{array}{l}a=5.3094(2), b=7.4994(2), c=5.1688(2) \\
\alpha=112.93(2), \beta=81.66(2), \gamma=113.12(1)\end{array}$ & $\begin{array}{l}P \overline{1}, 174.3 \\
3.27,2\end{array}$ & [9] \\
\hline \multicolumn{4}{|c|}{ 3. The Kosnarite, $\mathrm{KZr}_{2}\left(\mathrm{PO}_{4}\right)_{3}$ (NASICON) Structure Type (Rombohedral Analogues) } \\
\hline $\mathrm{Na}_{3} \mathrm{Fe}_{2}\left(\mathrm{PO}_{4}\right)_{3}$ & $a=8.7270(2), c=21.8078(5)$ & $\begin{array}{l}R \overline{3} c, 1438.38 \\
\quad 3.22,6\end{array}$ & [69] \\
\hline $\mathrm{Na}_{3} \mathrm{~V}_{2}\left(\mathrm{PO}_{4}\right)_{3}$ & $a=8.7288(2), c=21.8042(7)$ & $\begin{array}{l}R \overline{3} c, 1438.73 \\
\quad 3.16,6\end{array}$ & [68] \\
\hline $\mathrm{Li}_{3} \mathrm{Fe}_{2}\left(\mathrm{PO}_{4}\right)_{3}$ & $a=8.3162(4), c=22.459(1)$ & $\begin{array}{l}R \overline{3}, 1345.15 \\
\quad 3.09,6\end{array}$ & [69] \\
\hline $\mathrm{Na}_{4} \mathrm{MnV}\left(\mathrm{PO}_{4}\right)_{3}$ & $a=8.96354(2), c=21.448319(7)$ & $\begin{array}{l}R \overline{3} c, 1494.82 \\
\quad 3.25,6\end{array}$ & [73] \\
\hline \multicolumn{4}{|c|}{ 4. The Alluaudite, $\mathrm{Na}_{2} \mathrm{Mn}^{2+}\left(\mathrm{Fe}^{3+}, \mathrm{Fe}^{2+}\right)_{2}\left(\mathrm{PO}_{4}\right)_{3}$ Structure Type } \\
\hline $\begin{array}{l}\mathrm{Na}_{2} \mathrm{Fe}^{2+}\left(\mathrm{Fe}^{2+} \mathrm{Fe}^{3+}\right)\left(\mathrm{PO}_{4}\right)_{3} \\
\text { (ferroalluaudite) }\end{array}$ & $\begin{array}{c}a=10.923(1), b=6.500(1), c=12.538(2) \\
\gamma=98.3(1)\end{array}$ & $\begin{array}{c}I 112 / a^{* *}, 890.19 \\
3.71,4\end{array}$ & [79] \\
\hline$(\mathrm{Li}, \mathrm{Na}) \mathrm{MnFe}_{2}\left(\mathrm{PO}_{4}\right)_{3}$ & $\begin{array}{c}a=11.9892(2), b=12.4927(2), c=6.3859(1) \\
\beta=114.639(1)\end{array}$ & $\begin{array}{l}\mathrm{C} 2 / c, 869.34 \\
3.56,4\end{array}$ & [82] \\
\hline $\mathrm{Na}_{2} \mathrm{Fe}_{2}\left(\mathrm{SO}_{4}\right)_{3}$ & $\begin{array}{c}a=12.65847(7), b=12.77062(7) \\
c=6.51210(3) \beta=115.5391(4)\end{array}$ & $\begin{array}{l}C 2 / c, 949.86 \\
3.11,4\end{array}$ & [80] \\
\hline \multicolumn{4}{|c|}{ 5. The Wyllieite, $\mathrm{Na}_{2} \mathrm{Fe}^{2+}{ }_{2} \mathrm{Al}\left(\mathrm{PO}_{4}\right)_{3}$ Structure Type } \\
\hline $\mathrm{NaMn}^{2+}{ }_{2.5} \mathrm{Mn}^{3+}\left(\mathrm{PO}_{4}\right)_{3}$ & $\begin{array}{c}a=6.5291(6), b=12.653(1), c=10.952(1) \\
\beta=97.18(1)\end{array}$ & $\begin{array}{l}P 2_{1} / c, 897.68 \\
3.74,4\end{array}$ & [86] \\
\hline $\mathrm{Ag}_{1.09} \mathrm{Mn}_{3.46}\left(\mathrm{AsO}_{4}\right)_{3}$ & $\begin{array}{c}a=6.7470(7), b=12.9820(9), c=11.2970(8) \\
\beta=98.85(3)\end{array}$ & $\begin{array}{l}P 2_{1} / c, 977.72 \\
4.924\end{array}$ & [87] \\
\hline $\mathrm{Na}_{1.25} \mathrm{Co}^{2+}{ }_{2.187} \mathrm{Al}_{1.125}\left(\mathrm{AsO}_{4}\right)_{3}$ & $\begin{array}{c}a=6.532(2), b=12.492(2), c=11.060(2) \\
\beta=99.44(2)\end{array}$ & $\begin{array}{l}P 2_{1} / c, 890.3 \\
4\end{array}$ & [88] \\
\hline \multicolumn{4}{|c|}{ 6. The bradleyite, $\mathrm{Na}_{3} \mathrm{Mg}\left(\mathrm{CO}_{3}\right)\left(\mathrm{PO}_{4}\right)$ Structure Type } \\
\hline $\begin{array}{l}\mathrm{Na}_{3} \mathrm{Mn}\left(\mathrm{CO}_{3}\right)\left(\mathrm{PO}_{4}\right) \\
\text { (sidorenkite) }\end{array}$ & $\begin{array}{c}a=8.9859(1), b=6.73577(5), c=5.15998(4) \\
\beta=90.123(1)\end{array}$ & $\begin{array}{l}P 2_{1} / m, 312.31 \\
2.97,2\end{array}$ & [94] \\
\hline $\begin{array}{l}\mathrm{Na}_{3} \mathrm{Fe}\left(\mathrm{CO}_{3}\right)\left(\mathrm{PO}_{4}\right) \\
\quad \text { (bonshtedtite) }\end{array}$ & $\begin{array}{c}a=8.9542(1), b=6.61129(5), c=5.16023(5) \\
\beta=89.600(1)\end{array}$ & $\begin{array}{l}P 2_{1} / m, 305.47 \\
\quad 3.04,2\end{array}$ & [97] \\
\hline \multicolumn{4}{|c|}{ 7. The Natisite, $\mathrm{Na}_{2} \mathrm{TiSiO}_{5}$ Homeotypes } \\
\hline $\mathrm{Na}_{3} \mathrm{Fe}_{2}(\mathrm{OH})_{2} \mathrm{~F}\left(\mathrm{PO}_{4}\right)_{2}$ & $a=9.050(2), c=10.679(2)$ & $\begin{array}{c}P 4_{2} / m n m, 874.64 \\
3.22,8\end{array}$ & [100] \\
\hline $\mathrm{Na}_{3} \mathrm{Fe}_{2} \mathrm{~F}_{3}\left(\mathrm{PO}_{4}\right)_{2}$ & $a=6.399(1), c=10.679(3)$ & $\begin{array}{c}I 4 / \mathrm{mmm}, 429.11 \\
3.39,2\end{array}$ & [102] \\
\hline $\mathrm{Na}_{3} \mathrm{~V}_{2} \mathrm{O}_{2} \mathrm{~F}\left(\mathrm{PO}_{4}\right)_{2}$ & $a=6.3856(2), c=10.6119(9)$ & $\begin{array}{c}I 4 / \mathrm{mmm}, 431.05 \\
3.17,2\end{array}$ & [104] \\
\hline
\end{tabular}


Table 1. Cont

\begin{tabular}{|c|c|c|c|}
\hline Formula (Mineral Name) & Unit-Cell Parameters $a, b, c, \AA$ and $\alpha, \beta, \gamma^{\circ}$ & $\begin{array}{l}\text { Space Group, } V \AA^{3}, \\
\mathrm{~g} / \mathrm{cm}^{3}, Z\end{array}$ & Ref. \\
\hline \multicolumn{4}{|c|}{ 8. The Katiarsite, $\mathrm{KTiO}\left(\mathrm{AsO}_{4}\right)$ (KTP) Structure Type } \\
\hline $\mathrm{KFeF}\left(\mathrm{PO}_{4}\right)$ & $a=12.885(6), b=6.370(2), c=10.656(4)$ & $\begin{array}{l}\text { Pna } 2_{1}, 874.62 \\
3.17,8\end{array}$ & [131] \\
\hline $\mathrm{KVF}\left(\mathrm{PO}_{4}\right)$ & $a=12.8200(3), b=6.3952(1), c=10.6115(2)$ & $\begin{array}{l}\text { Pna }_{1}, 869.99 \\
3.11,8\end{array}$ & [110] \\
\hline $\mathrm{KVO}\left(\mathrm{PO}_{4}\right)$ & $a=12.816(5), b=6.388(2), c=10.556(5)$ & $\begin{array}{l}\text { Pna }_{1}, 864.21 \\
3.09,8\end{array}$ & [113] \\
\hline $\mathrm{KTiF}\left(\mathrm{PO}_{4}\right)$ & $a=13.0020(2), b=6.43420(8), c=10.7636(2)$ & $\begin{array}{l}\text { Pna } 2_{1}, 900.45 \\
3.01,8\end{array}$ & [115] \\
\hline \multicolumn{4}{|c|}{ 9. The Arrojadite, $\mathrm{KNa}_{4} \mathrm{Ca}(\mathrm{Fe}, \mathrm{Mn})_{14} \mathrm{Al}\left(\mathrm{PO}_{4}\right)_{12}(\mathrm{OH}, \mathrm{F})_{2}$ Structure Type } \\
\hline $\begin{array}{c}\mathrm{KNa}_{5} \mathrm{Fe}^{2+}{ }_{14} \mathrm{Fe}^{3+}\left(\mathrm{PO}_{4}\right)_{12}(\mathrm{OH})_{2} \\
\text { (arrojadite) }\end{array}$ & $\begin{aligned} a=16.53(2), b & =10.084(9), c=24.64(3) \\
\beta & =105.75(7)\end{aligned}$ & $\begin{array}{c}C 12 / c 1,3953 \\
3.69,4\end{array}$ & [120] \\
\hline
\end{tabular}

Author Contributions: Conceptualization, O.Y.; validation, N.K., E.A.; writing, original draft preparation, O.Y., N.K.; writing, review and editing, O.Y., N.K., E.A. All authors contributed equally. All authors have read and agreed to the published version of the manuscript.

Funding: This research was funded by Russian Foundation for Basic Research (RFBR grant No. 18-29-12076 mk).

Conflicts of Interest: The authors declare no conflict of interest.

\section{References}

1. The Nobel Prize. Available online: https://www.nobelprize.org/prizes/chemistry/2019/press-release/ (accessed on 22 April 2020).

2. Kubota, K.; Dahbi, M.; Hosaka, T.; Kumakura, S.; Komaba, S. Towards K-Ion and Na-Ion Batteries as “Beyond Li-Ion". Chem. Rec. 2018, 18, 459-479. [CrossRef]

3. Padhi, A.K.; Nanjundaswamy K., S.; Goodenough, J.B. Phospho-olivines as positive-electrode materials for rechargeable lithium batteries. J. Electrochem. Soc. 1997, 144, 1188-1194. [CrossRef]

4. Phosphates: Geochemical, Geobiological and Materials Importance. In Mineralogical Society of America and Geochemical Society Reviews in Mineralogy and Geochemistry; Kohn, M.J., Rakovan, J., Hughes, J.M., Eds.; Walter de Gruyter GmbH \& Co KG: Berlin, Germany, 2002; p. 742.

5. Goodenough, J.B.; Kim, Y. Challenges for Li Rechargeable Batteries. Chem. Mater. 2010, 22, 587-603. [CrossRef]

6. Mizushima, K.; Jones, P.C.C.; Wiseman, P.J.; Goodenough, J.B. $\mathrm{Li}_{\mathrm{x}} \mathrm{CoO}_{2}(0<\mathrm{x}<-1)$ : A new cathode material for batteries of high energy density. Mater. Res. Bull. 1980, 15, 783-789.

7. Whittingham, M.S. Ultimate Limits to Intercalation Reactions for Lithium Batteries. Chem. Rev. 2014, 114, 11414-11443. [CrossRef]

8. Masquelier, C.; Croguennec, L. Polyanionic (Phosphates, Silicates, Sulfates) Frameworks as Electrode Materials for Rechargeable Li (or Na) Batteries. Chem. Rev. 2013, 113, 6552-6591. [CrossRef] [PubMed]

9. Antipov, E.V.; Khasanova, N.R.; Fedotov, S.S. Perspectives on Li and transition metal fluoride phosphates as cathode materials for a new generation of Li-ion batteries. IUCr J. 2015, 2, 85-94. [CrossRef] [PubMed]

10. Larcher, D.; Tarascon, J.-M. Towards greener and more sustainable batteries for electrical energy storage. Nat. Chem. 2015, 7, 19-29. [CrossRef]

11. Kim, H.; Kim, J.C.; Bianchini, M.; Seo, D.-H.; Rodriguez-Garcia, J.; Ceder, G. Recent Progress and Perspective in Electrode Materials for K-Ion Batteries. Adv. Energy Mater. 2018, 8, 1702384. [CrossRef]

12. London, D.; Kontak, D.J. Granitic Pegmatites: Scientific wonders and economic bonanzas. Elements 2012, 8, 257-261. [CrossRef] 
13. Moore, P.B. Pegmatite phosphates: Descriptive mineralogy and crystal chemistry. Mineral. Rec. 1973, 4, 103-130.

14. Fisher, D.G. Geochemistry of Phosphorus Containing Minerals. In Environmental Phosphorus Handbook; Griffith, E., Beeton, A., Spenser, J., Eds.; Wiley: New York, NY, USA, 1973.

15. Černý, P.; Ercit, S. The classification of granitic pegmatites revisited. Can. Mineral. 2005, 43, $2005-2026$. [CrossRef]

16. Keller, P.; Fransolet, A.-M.; Fontan, F. Triphylite-lithiophilite and triplite-zwieselite in granitic pegmatites: Their textures and genetic relationships. N. Jahrb. Mineral. Abh. 1994, 168, 127-145.

17. Moore, P.B. Crystallochemical Aspects of the Phosphate Minerals. In Phosphate Minerals; Nriagu, J.O., Moore, P.B., Eds.; Springer: Berlin/Heidelberg, Germany, 1984; pp. 155-170.

18. Moore, P.B. The primary pegmatite phosphate minerals. The mineralogy of pegmatites, Brown, G.E., Jr. Amer. Miner. 1982, 67, 180-189.

19. Mücke, A. The paragenesis of the phosphate minerals of the Hagendorf pegmatite-A general view. Chem. Erde. 1981, 40, 217-237.

20. Sandomirskii, P.A.; Belov, N.V. Crystal Chemistry of Mixed Anionic Radicals; Nauka: Moscow, Russia, 1984. (In Russian)

21. Yakubovich, O.V.; Urusov, V.S. The genetic crystal chemistry of pegmatite phosphates. Mosc. Univ. Geol. Bull. 1996, 51, 18-40.

22. Yakubovich, O.V. Phosphates with amphoteric oxo-complexes: From structural features to genetic conclusions. Z. Krist. 2008, 223, 126-131. [CrossRef]

23. Yakubovich, O.V. Phosphates with Amphoteric Oxocomplexes: Crystal Chemical Features and Expected Physical Properties In Minerals as Advanced Materials I; Krivovichev, S., Ed.; Springer: Berlin/Heidelberg, Germany, 2008; p. 255.

24. Shigley, J.E.; Brown, G.E. Lithiophilite formation in granitic pegmatites: A reconnaissance experimental study of phosphate crystallization from hydrous aluminosilicate melts. Am. Mineral. 1986, 71, 356-366.

25. Eventoff, W.; Martin, R.; Peacor, D.R. The crystal structure of heterosite. Am. Mineral. 1972, 57, 45-51.

26. Iakubovich, O.V.; Simonov, M.A.; Belov, N.V. Crystal structure of synthetic triphyline $\left.\mathrm{LiFe}_{\mathrm{PO}}\right]$. Dokl. Akad. Nauk SSSR 1977, 235, 93-95.

27. Ravet, N.; Chouinard, Y.; Magnan, J.F.; Besner, S.; Gauthier, M.; Armand, M. Electroactivity of natural and synthetic triphilyte. J. Power Sources 2001,97-98, 503-507. [CrossRef]

28. Huang, H.; Yin, S.C.; Nazar, L.F. Approachim theoretical capacity of LiFePO4 at room temperature at high rates. Electrochem. Solid State Lett. 2001, 4, A170-A172. [CrossRef]

29. Dominko, R.; Gaberšček, M.; Drofenik, J.; Bele, M.; Pejovnik, S. A Novel Coating Technology for Preparation of Cathodes in Li-Ion Batteries. Electrochem. Solid State Lett. 2001, 4, A187-A190. [CrossRef]

30. Chung, S.-J.; Bloking, J.T.; Chiang, Y.M. Electronically conductive phospho-olivines as lithium storage electrodes. Nat. Mat. 2002, 1, 123-128. [CrossRef]

31. Morgan, D.; Van der Ven, A.; Ceder, G. Li Conductivity in $\mathrm{LixMPO}_{4}(\mathrm{M}=\mathrm{Mn}, \mathrm{Fe}, \mathrm{Co}, \mathrm{Ni})$ Olivine Materials. Electrochem. Solid-State Lett. 2004, 7, A30-A32. [CrossRef]

32. Islam, M.S.; Driscoll, D.J.; Fisher, C.A.; Slater, P.R. Atomic-Scale Investigation of Defects, Dopants, and Lithium Transport in the $\mathrm{LiFePO}_{4}$ Olivine-Type Battery Material. Chem. Mater. 2005, 17, 5085-5092. [CrossRef]

33. Nishimura, S.; Kobayashi, G.; Ohoyama, K.; Kanno, K.; Yashima, M.; Yamada, A. Experimental visualization of lithium diffusion in $\mathrm{Li}_{x} \mathrm{FePO}_{4}$. Nat. Mater. 2008, 7, 707-711. [CrossRef]

34. Qin, X.; Wang, X.; Xiang, H.; Xie, J.; Li, J.; Zhou, Y. Mechanism for Hydrothermal Synthesis of LiFePO Platelets as Cathode Material for Lithium-Ion Batteries. J. Phys. Chem. C 2010, 114, 16806-16812. [CrossRef]

35. Sharikov, F.Y.; Drozhzhin, O.A.; Sumanov, V.D.; Baranov, A.N.; Abakumov, A.M.; Antipov, E.V. Exploring the Peculiarities of LiFePO4 Hydrothermal Synthesis Using In Situ Calvet Calorimetry. Cryst. Growth Des. 2018, 18, 879-882. [CrossRef]

36. Ravnsbæk, D.B.; Xiang, K.; Xing, W.; Borkiewicz, O.J.; Wiaderek, K.M.; Gione, P.; Chapman, K.W.; Chupas, P.J.; Chiang, Y.-M. Extended Solid Solutions and Coherent Transformations in Nanoscale Olivine Cathodes. Nano Lett. 2014, 14, 1484-1491.

37. Yakubovich, O.V.; Karimova, O.V.; Melnikov, O.K.; Urusov, V.S. Crystal structure of $\left(\mathrm{NH}_{4}\right)\left(\mathrm{FePO}_{4}\right) \mathrm{HF}-$ niahite synthetic variant. Dokl. Akad. Nauk SSSR 1995, 342, 40-44. 
38. Yakubovich, O.V.; Karimova, O.V.; Dimitrova, O.V.; Mass, A.W. Layer structure of $\left(\mathrm{NH}_{4}\right) \mathrm{CoPO}_{4} \mathrm{H}_{2} \mathrm{O}$. Acta Cryst. C 1999, 55, 151-153. [CrossRef]

39. Bridge, P.J.; Robinson, B.W. Niahite-a new mineral from Malaysia. Mineral. Mag. 1983, 47, 79-80. [CrossRef]

40. Livage, J. Chimie douce: From shake-and-bake processing to wet chemistry. New J. Chem. 2001, $25,1$. [CrossRef]

41. Kiriukhina, G.V.; Yakubovich, O.V.; Dimitrova, O.V. Crystal structure of a new polymorphic modification of niahite, $\mathrm{NH}_{4} \mathrm{MnPO}_{4} \mathrm{H}_{2}$ O. Cryst. Rep. 2015, 60, 198-203. [CrossRef]

42. Wu, C.; Xie, J.; Cao, G.; Zhao, X.; Zhang, S. Ordered LiMPO4 (M = Fe, Mn) nanorods synthesized from $\mathrm{NH}_{4} \mathrm{MPO}_{4} \cdot \mathrm{H}_{2} \mathrm{O}$ microplates by stress involved ion exchange for Li-ion batteries. Cryst. Eng. Comm. 2014, 16, 2239-2245. [CrossRef]

43. Bramnik, N.; Ehrenberg, H. Precursor-based synthesis and electrochemical performance of $\mathrm{LiMnPO}_{4}$. J. Alloys Compd. 2008, 464, 259-264. [CrossRef]

44. Alyoshin, V.A.; Pleshakov, E.A.; Ehrenberg, H.; Michailova, D. Platelike $\mathrm{LiMPO}_{4}(\mathrm{M}=\mathrm{Fe}, \mathrm{Mn}, \mathrm{Co}, \mathrm{Ni})$ for Possible Application in Rechargeable Li Ion Batteries: Beyond Nanosize. J. Phys. Chem. C 2014, 118, 17426-17435. [CrossRef]

45. Yakubovich, O.V.; Bairakov, V.V.; Simonov, M.A. Crystal structure of simferite $\mathrm{Li}\left(\mathrm{Mg}, \mathrm{Fe}^{3+}, \mathrm{Mn}^{3+}\right)_{2}\left[\mathrm{PO}_{4}\right]_{2}$. Soviet Physics Doklady. 1989, 34, 669-671.

46. Omenya, F.; Miller, J.K.; Fang, J.; Wen, B.; Zhang, R.; Wang, Q.; Chernova, N.A.; Whittingham, M.S. Single-Phase Lithiation and Delithiation of Simferite Compounds $\mathrm{Li}(\mathrm{Mg}, \mathrm{Mn}, \mathrm{Fe}) \mathrm{PO}_{4}$. Chem. Mater. 2014, 26, 6206-6212. [CrossRef]

47. Moore, P.B. Crystal chemistry of the basic iron phosphates. Am. Mineral. 1970, 55, 135-169.

48. Yakubovich, O.V.; Urusov, V.S. The structure and electron density of $\mathrm{Fe}^{2+}$-bearing tavorite in relation to the genetic crystal chemistry of secondary phosphates of lithium pegmatites. Geochem. Intern. 1997, 35, 630-638.

49. Marx, N.; Croguennec, L.; Carlier, D.; Wattiaux, A.; Le Cras, F.; Suard, E.; Delmas, C. The structure of tavorite $\mathrm{LiFePO}_{4}(\mathrm{OH})$ from diffraction and GGA $+U$ studies and its preliminary electrochemical characterization. Dalton Trans. 2010, 39, 5108-5116. [CrossRef]

50. Barker, J.; Gover, R.K.B.; Burns, P.; Bryan, A. LiVPO 4 F: A new active material for safe lithium-ion batteries. Electrochem. Solid-State Lett. 2005, 8, A285-A287. [CrossRef]

51. Vignola, P.; Hatert, F.; Fransolet, A.-M.; Medenbach, O.; Diella, V.; Andò, S. Karenwebberite, $\mathrm{Na}\left(\mathrm{Fe}^{2+}, \mathrm{Mn}^{2+}\right) \mathrm{PO}_{4}$, a new member of the triphylite group from the Malpensata pegmatite, Lecco Province, Italy. Am. Mineral. 2013, 98, 767-772. [CrossRef]

52. Moore, P.B. Natrophilite, NaMn(PO4), has ordered cations. Am. Mineral. 1972, 57, 1333-1344.

53. Moreau, P.; Guyomard, D.; Gaubicher, J.; Boucher, F. Structure and Stability of Sodium Intercalated Phases in Olivine $\mathrm{FePO}_{4}$. Chem. Mater. 2010, 22, 4126-4128. [CrossRef]

54. Yabuuchi, N.; Kubota, K.; Dahbi, M.; Komaba, S. Research Development on Sodium-Ion Batteries. Chem. Rev. 2014, 114, 11636-11682. [CrossRef]

55. Casas-Cabanas, M.; Roddatis, V.V.; Saurel, D.; Kubiak, P.; Carretero-Gonzalez, J.; Palomares, V.; Serras, P.; Rojo, T. Crystal chemistry of $\mathrm{Na}$ insertion/deinsertion in $\mathrm{FePO}_{4}-\mathrm{NaFePO}_{4}$. J. Mater. Chem. 2012, 22, 1742-17423. [CrossRef]

56. Le Page, Y.; Donnay, G. The crystal structure of the new mineral marićite, NaFePO4. Can. Mineral. 1977, 15, 518-521.

57. Yakubovich, O.V.; Urusov, V.S. Electron density distribution in lithiophosphatite $\mathrm{Li}_{3} \mathrm{PO}_{4}$ : Crystallochemical features of orthophosphates with hexagonal close packing. Cryst. Rep. 1997, 42, 261-268.

58. Corlett, M.I.; Armbruster, T. Structural relations between marićite and natrophilite in the system $\mathrm{NaFePO}_{4}-\mathrm{NaMnPO}_{4}$. GAC-MAC Join Annu. Meet. 1979, 4, 1979.

59. Kim, J.; Seo, D.-H.; Kim, H.; Park, I.; Yoo, Y.-K.; Jung, S.-K.; Park, Y.-U.; Goddard, W.A.; Kang, K. Unexpected discovery of low-cost maricite $\mathrm{NaFePO} 4$ as a high-performance electrode for $\mathrm{Na}$-ion batteries. Energy Environ. Sci. 2015, 8, 540-545. [CrossRef]

60. Moore, P.B. Sarcopside: Its atomic arrangement. Am. Mineral. 1972, 57, 24-35.

61. Omenya, F.; Chernova, N.A.; Zhang, R.; Fang, J.; Huang, Y.; Cohen, F.; Dobrzynski, N.; Senanayake, S.; $\mathrm{Xu}$, W.; Whittingham, M.S. Why Substitution Enhances the Reactivity of LiFePO 4 . Chem. Mater. 2013, 25, 85-89. [CrossRef] 
62. Janssen, Y.; Santhanagopalan, D.; Qian, D.; Chi, M.; Wang, X.; Hoffmann, C.; Meng, Y.S.; Khalifah, P. Reciprocal Salt Flux Growth of $\mathrm{LiFePO}_{4}$ Single Crystals with Controlled Defect Concentrations. Chem. Mater. 2013, 25, 4574-4584. [CrossRef]

63. Crouzet, C.; Recham, N.; Brunet, F.; Findling, N. A novel route for FePO4 olivine synthesis from sarcopside oxidation. Solid State Sci. 2016, 62, 29-33. [CrossRef]

64. Bnownfield, M.-E.; Foord, E.E.; Sutley, S.J.; Botinelly, T. Kosnarite, $\mathrm{KZr}_{2}\left(\mathrm{PO}_{4}\right)_{3}$, a new mineral from Mount Mica and Black Mountain, Oxford County, Maine. Am. Mineral. 1993, 78, 653-656.

65. Šljukić, M.; Matković, B.; Prodić, B.; Anderson, D. The crystal structure of $\mathrm{KZr}_{2}\left(\mathrm{PO}_{4}\right)_{3}$. Z. Krist. 1969, 130, 148-161. [CrossRef]

66. D'Yvoire, F.; Pintard-Screpel, M.; Bretey, E.; De la Roche're, M. Phase transitions and ionic conduction in 3D skeleton phosphates $\mathrm{A}_{3} \mathrm{M}_{2}\left(\mathrm{PO}_{4}\right)_{3}: \mathrm{A}=\mathrm{Li}, \mathrm{Na}, \mathrm{Ag}, \mathrm{K} ; \mathrm{M}=\mathrm{Cr}$, Fe. Solid State Ionics 1983, 9-10, 851-857. [CrossRef]

67. Gaubicher, J.; Wurm, C.; Goward, G.; Masquelier, C.; Nazar, L.F. Rhombohedral Form of $\operatorname{Li}_{3} \mathrm{~V}_{2}\left(\mathrm{PO}_{4}\right)_{3}$ as a Cathode in Li-Ion Batteries. Chem. Mater. 2000, 12, 3240-3242. [CrossRef]

68. Zatovsky, I.V. NASICON-type Na3V2(PO4)3. Acta Cryst. 2010, E66, i12. [CrossRef] [PubMed]

69. Masquelier, C.; Wurm, C.; Rodriguez-Carvajal, J.; Gaubicher, J.; Nazar, L.F. A Powder Neutron Diffraction Investigation of the Two Rhombohedral NASICON Analogues: $\gamma-\mathrm{Na}_{3} \mathrm{Fe}_{2}\left(\mathrm{PO}_{4}\right)_{3}$ and $\mathrm{Li}_{3} \mathrm{Fe}_{2}\left(\mathrm{PO}_{4}\right)_{3}$. Chem. Mater. 2000, 12, 522-532. [CrossRef]

70. Chen, S.; Wu, C.; Shen, L.; Zhu, C.; Huang, Y.; Xi, K.; Maier, J.; Yu, Y. Challenges and Perspectives for NASICON-Type Electrode Materials for Advanced Sodium-Ion Batteries. Adv. Mater. 2017, $29,170043$. [CrossRef]

71. Jian, Z.; Han, W.; Liang, Y.; Lan, Y.; Fang, Z.; Hu, Y.-S.; Yao, Y. Carbon-coated rhombohedral $\mathrm{Li}_{3} \mathrm{~V}_{2}\left(\mathrm{PO}_{4}\right)_{3}$ as both cathode and anode materials for lithium-ion batteries: Electrochemical performance and lithium storage mechanism. J. Mater. Chem. A 2014, 2, 20231-20236. [CrossRef]

72. Zhou, W.; Xue, L.; Lü, X.; Gao, H.; Li, Y.; Xin, S.; Fu, G.; Cui, Z.; Zhu, Y.; Goodenough, J.B. Na $\mathrm{NV}_{\mathbf{x}}\left(\mathrm{PO}_{4}\right)_{3}$ $(\mathrm{M}=\mathrm{Mn}, \mathrm{Fe}, \mathrm{Ni})$ Structure and Properties for Sodium Extraction. Nano Lett. 2016, 16, 7836-7841. [CrossRef]

73. Chen, F.; Kovrugin, V.M.; David, R.; Mentré, O.; Fauth, F.; Chotard, J.-N.; Masquelier, C. A NASICON-Type Positive Electrode for $\mathrm{Na}$ Batteries with High Energy Density: $\mathrm{Na}_{4} \mathrm{MnV}\left(\mathrm{PO}_{4}\right)_{3}$. Small Methods 2018, 3, 1800218. [CrossRef]

74. Zakharkin, M.V.; Drozhzhin, O.A.; Tereshchenko, I.V.; Chernyshov, D.; Abakumov, A.M.; Antipov, E.V.; Stevenson, K.J. Enhancing Na+ Extraction Limit through High Voltage Activation of the NASICON-Type Na4MnV(PO4)3 Cathode. Appl. Energy Mater. 2018, 1, 5842-5846. [CrossRef]

75. Mindat.org. Available online: https://www.mindat.org/min-142.html (accessed on 22 April 2020).

76. Moore, P.B. Crystal chemistry of the alluaudite structure type: Contribution to the paragenesis of pegmatite phosphate giant crystals. Am. Mineral. 1971, 56, 1955-1975.

77. Hatert, F. The crystal chemistry of lithium in the alluaudite structure: A study of the $\left(\mathrm{Na}_{1-\mathrm{x}} \mathrm{Li}_{\mathrm{x}}\right)_{1.5} \mathrm{Mn}_{1.5} \mathrm{Fe}_{1.5}\left(\mathrm{PO}_{4}\right)_{3}$ solid solution ( $\mathrm{x}=0$ to 1). Mineral. Petrol. 2004, 81, 205-217. [CrossRef]

78. Hatert, F.; Ottolini, L.; Schmid-Beurmann, P. Experimental investigation of the alluaudite+triphlyite assemblage, and development of the Na-in-triphylite geothermometer: Application to natural pegmatite phosphates. Contrib. Mineral. Petrol. 2011, 161, 531-546. [CrossRef]

79. Iakubovich, O.V.; Simonov, M.A.; Egorov-Tismenko, I.K.; Belov, N.V. Crystal structure of $\mathrm{Na}_{2}\left(\mathrm{Fe}_{0.5}{ }^{3+} \mathrm{Fe}_{0.5}{ }^{2+}\right)_{2} \mathrm{Fe}^{2+}\left[\mathrm{PO}_{4}\right]_{3}$-synthetic variety of alluaudite. Dokl. Akad. Nauk SSSR. 1977, 236, 1123-1126.

80. Barpanda, P.; Oyama, G.; Nishimura, S.I.; Chung, S.C.; Yamada, A. A 3.8-V earth- abundant sodium battery electrode. Nat. Commun. 2014, 5, 4358. [CrossRef]

81. Zhang, P.; Yang, K.; Song, L.; Feng, H.-J.; Gao, J. An alluaudite-type sodium-ion battery cathode candidate $\mathrm{Na}_{2} \mathrm{Mn}_{2} \mathrm{~V}\left(\mathrm{PO}_{4}\right)_{3}$ : Crystal growth, preparation, structure and electrochemical properties. J. Alloys Compd. 2019, 783, 409-415. [CrossRef]

82. Tard, K.; Carlier, D.; Croguennec, L.; Wattiaux, A.; Ben Amara, M.; Delmas, C. Structural study of the $\mathrm{Li}_{(0.5)} \mathrm{Na}_{(0.5)} \mathrm{MnFe}_{2}\left(\mathrm{PO}_{4}\right)_{3}$ and $\mathrm{Li}_{(0.75)} \mathrm{Na}_{(0.25)} \mathrm{MnFe}_{2}\left(\mathrm{PO}_{4}\right)_{3}$ alluaudite phases and their electrochemical properties as positive electrodes in lithium batteries. Inorg. Chem. 2010, 49, 10378-10389. [CrossRef] [PubMed] 
83. Moore, P.B.; Ito, J. Wyllieite, $\mathrm{Na}_{2} \mathrm{Fe}^{2+}{ }_{2} \mathrm{Al}\left[\mathrm{PO}_{4}\right]_{3}$, a new species. Mineral. Rec. 1973, 4, 131-136.

84. Moore, P.B.; Ito, J. Alluaudites, wyllieites, arrojadites: Crystal chemistry and nomenclature. Mineral. Mag. 1979, 6, 227-235. [CrossRef]

85. Yang, H.; Downs, R.T.; Gu, X.; Xie, X.; Kobsch, A. Fupingqiuite, IMA 2016-087. CNMNC Newsletter No. 35, February 2017, 211. Mineral. Mag. 2017, 81, 209-213.

86. Yakubovich, O.V.; Massa, W.; Gavrilenko, P.; Dimitrova, O. The crystal structure of new synthetic member in the wyllieite group: $\mathrm{Na}_{1.265} \mathrm{Mn}^{2+}{ }_{2.690} \mathrm{Mn}^{3+}{ }_{0.785}\left(\mathrm{PO}_{4}\right)_{3}$. Eur. J. Mineral. 2005, 17, 741-747. [CrossRef]

87. Frigui, W.; Zid, M.F.; Driss, A. Wyllieite-type $\mathrm{Ag}_{1.09} \mathrm{Mn}_{3.46}\left(\mathrm{AsO}_{4}\right)_{3}$. Acta Cryst. 2012, E68, i40-i41. [CrossRef]

88. Marzouki, R.; Ben Smida, Y.; Avdeev, M.; Alghamdi, M.M.; Zid, M.F. Synthesis, structure and $\mathrm{Na}^{+}$migration pathways of new Wylleite-type $\mathrm{Na}_{1.25} \mathrm{Co}_{2.187} \mathrm{Al}_{1.125}\left(\mathrm{AsO}_{4}\right)_{3}$. Mater. Res. Express 2019, 6, 126313. [CrossRef]

89. Khomyakov, A.P.; Semenov, E.I.; Kazakova, M.E.; Shumyatskaya, N.G. Sidorenkite, $\mathrm{Na}_{3} \mathrm{Mn}\left(\mathrm{PO}_{4}\right)\left(\mathrm{CO}_{3}\right)$, a new mineral. Zapiski VMO 1979, 108, 56-59. (In Russian) [CrossRef]

90. Khomyakov, A.P.; Aleksandrov, V.V.; Krasnova, N.I.; Ermilov, V.V.; Smolyaninova, V.V. Bonshtedtite, $\mathrm{Na}_{3} \mathrm{Fe}\left(\mathrm{PO}_{4}\right)\left(\mathrm{CO}_{3}\right)$, a new mineral. Zapiski VMO 1982, 111, 486-490. (In Russian) [CrossRef]

91. Kurova, T.A.; Shumyatskaya, N.G.; Voronkov, A.A.; Pyatenko, Y.A. Crystal structure of sidorenkite $\mathrm{Na}_{3} \mathrm{Mn}\left(\mathrm{PO}_{4}\right)\left(\mathrm{CO}_{3}\right)$. Dokl. Akad. Nauk. SSSR 1980, 251, 605-607.

92. Krivovichev, S.V.; Chernyatieva, A.P.; Britvin, S.N.; Yakovenchuk, V.N.; Krivovichev, V.G. Refinement of the crystal structure of bonshtedtite, $\mathrm{Na}_{3} \mathrm{Fe}\left(\mathrm{PO}_{4}\right)\left(\mathrm{CO}_{3}\right)$. Geol. Ore Depos. 2013, 55, 669-675. [CrossRef]

93. Hautier, G.; Jain, A.; Chen, H.; Moore, C.; Ong, S.P.; Ceder, G. Novel mixed polyanions lithium-ion battery cathode materials predicted by high-throughput ab initio computations. J. Mater. Chem. 2011, 21, 17147-17153. [CrossRef]

94. Chen, H.; Hao, Q.; Zivkovic, O.; Hautier, G.; Du, L.-S.; Tang, Y.; Hu, Y.-Y.; Ma, X.; Grey, C.P.; Ceder, G. Sidorenkite $\left(\mathrm{Na}_{3} \mathrm{MnPO}_{4} \mathrm{CO}_{3}\right)$ : A New Intercalation Cathode Material for Na-Ion Batteries. Chem. Mater. 2013, 25, 2777-2787. [CrossRef]

95. Wang, C.; Sawicki, M.; Emani, S.; Liu, C.; Shaw, L.L. $\mathrm{Na}_{3} \mathrm{MnCO}_{3} \mathrm{PO}_{4}-\mathrm{A}$ High Capacity, Multi-Electron Transfer Redox Cathode Material for Sodium Ion Batteries. Electrochim. Acta 2015, 161, 322-328. [CrossRef]

96. Hassanzadeh, N.; Sadrnezhaad, S.K.; Chen, G. In-situ hydrothermal synthesis of $\mathrm{Na}_{3} \mathrm{MnCO}_{3} \mathrm{PO}_{4} / \mathrm{rGO}$ hybrid as a cathode for Na-ion battery. Electrochim. Acta 2016, 208, 188-194. [CrossRef]

97. Huang, W.; Zhou, J.; Li, B.; Ma, J.; Tao, S.; Xia, D.; Chu, W.; Wu, Z. Detailed investigation of $\mathrm{Na}_{2.24} \mathrm{FePO}_{4} \mathrm{CO}_{3}$ as a cathode material for Na-ion batteries. Sci. Rep. 2014, 4, 4188. [CrossRef]

98. Men'shikov, Y.P.; Pakhomovskii, Y.A.; Goiko, E.A.; Bussen, I.V.; Mer'kov, A.N. A natural tetragonal titanosilicate of sodium, natisite. Zapiski VMO 1975, 104, 314-317. (In Russian)

99. Nyman, H.; O'Keeffe, M.; Bovin, J.O. Sodium titanium silicate, Na $\mathrm{NiSiO}_{5}$. Acta Cryst. 1978, B34, $905-906$. [CrossRef]

100. Yakubovich, O.V.; Simonov, M.A.; Melnikov, O.K. The mixed Fe-P framework in the crystal structure of $\mathrm{Na}_{3} \mathrm{Fe}_{2}{ }^{3+}\left[\mathrm{PO}_{4}\right]_{2}(\mathrm{OH})_{2}$ F. Kristallografiya 1984, 29, 484-488.

101. Slobodyanik, N.S.; Nagornyi, P.C.; Kornienko, Z.I.; Kapshuk, A.A.; Mitkevich, V.V. Preparation and crystal structure of $\mathrm{Na}_{3} \mathrm{Cr}_{2} \mathrm{~F}_{3}\left(\mathrm{PO}_{4}\right)_{2}$. Russ. J. Inorg. Chem. 1989, 34, 1413-1414.

102. Yakubovich, O.V.; Melnikov, O.K.; Urusov, V.S. The framework of mixed nature in $\mathrm{Na}_{3}\left\{\mathrm{Fe}_{2} \mathrm{~F}_{3}\left[\mathrm{PO}_{4}\right]_{2}\right\}$ crystal structure-a new homeotype in the series of natisite. Dokl. Akad. Nauk SSSR 1995, 342, 615-620.

103. Yakubovich, O.V.; Melnikov, O.K. Anionic framework of a mixed type in $\mathrm{Na}_{3}\left\{\mathrm{Al}_{2} \mathrm{~F}_{3}\left[\mathrm{PO}_{4}\right]_{2}\right\}$ crystalline structure. Kristallografiya 1996, 41, 663-668.

104. Massa, W.; Yakubovich, O.V.; Dimitrova, O.V. Crystal structure of a new sodium vanadyl(IV) fluoride phosphate $\mathrm{Na}_{3}\left\{\mathrm{~V}_{2} \mathrm{O}_{2} \mathrm{~F}\left[\mathrm{PO}_{4}\right]_{2}\right\}$. Solid State Sci. 2002, 4, 495-501. [CrossRef]

105. Serras, P.; Palomares, V.; Goni, A.; Gil de Muro, I.; Kubiak, P.; Lezama, L.; Rojo, T. High voltage cathode materials for Na-ion batteries of general formula $\mathrm{Na}_{3} \mathrm{~V}_{2} \mathrm{O}_{2 x}\left(\mathrm{PO}_{4}\right)_{2} \mathrm{~F}_{3-2 x}$. J. Mater. Chem. 2012, 22, 22301-22308. [CrossRef]

106. Park, Y.U.; Seo, D.H.; Kwon, H.S.; Kim, B.; Kim, J.; Kim, H.; Kim, I.; Yoo, H.-I.; Kang, K. A new high-energy cathode for a Na-ion battery with ultrahigh stability. J. Am. Chem. Soc. 2013, 135, 13870-13878. [CrossRef]

107. Broux, T.; Bamine, T.; Fauth, F.; Simonelli, L.; Olszewski, W.; Marini, C.; Meneétrier, M.; Carlier, D.; Masquelier, C.; Croguennec, L. Strong impact of the oxygen content in $\mathrm{Na}_{3} \mathrm{~V}_{2}\left(\mathrm{PO}_{4}\right)_{2} \mathrm{~F}_{3-\mathrm{y}} \mathrm{O}_{\mathrm{y}}(0 \leq \mathrm{y} \leq 0.5)$ on its structural and electrochemical properties. Chem. Mater. 2016, 28, 7683-7692. [CrossRef] 
108. Pekov, I.V.; Yapaskurt, V.O.; Britvin, S.N.; Zubkova, N.V.; Vigasina, M.F.; Sidorov, E.G. New arsenate minerals from the Arsenatnaya fumarole, Tolbachik volcano, Kamchatka, Russia. V. Katiarsite, $\mathrm{KTiO}\left(\mathrm{AsO}_{4}\right)$. Miner. Mag. 2016, 80, 639-646. [CrossRef]

109. Pekov, I.V.; Zubkova, N.V.; Agakhanov, A.A.; Yapaskurt, V.O.; Belakovskiy, D.I.; Vigasina, M.F.; Britvin, S.N.; Turchkova, A.G.; Sidorov, E.G.; Pushcharovsky, D.Y. Yurgensonite, IMA 2019-059. CNMNC Newsletter No. 52. Mineral. Mag. 2019, 83. [CrossRef]

110. Recham, N.; Gwenaelle, R.; Sougrati, M.T.; Chotard, J.-N.; Frayret, C.; Mariyappan, S.; Melot, B.C.; Jumas, J.-C.; Tarascon, J.-M. Preparation and Characterization of a Stable $\mathrm{FeSO}_{4} \mathrm{~F}$-Based Framework for Alkali Ion Insertion Electrodes. Chem. Mater. 2012, 24, 4363-4370. [CrossRef]

111. Fedotov, S.S.; Khasanova, N.R.; Samarin, A.S.; Drozhzhin, O.A.; Batuk, D.; Karakulina, O.M.; Hadermann, J.; Abakumov, A.M.; Antipov, E.V. AVPO 4 F (A = Li, K): A 4 V Cathode Material for High-Power Rechargeable Batteries. Chem. Mater. 2016, 28, 411-415. [CrossRef]

112. Nikitina, V.A.; Fedotov, S.S.; Vassiliev, S.Y.; Samarin, A.S.; Khasanova, N.R.; Antipov, E.V. Transport and Kinetic Aspects of Alkali Metal Ions Intercalation into $\mathrm{AVPO}_{4} \mathrm{~F}$ Framework. J. Electrochem. Soc. 2017, 164, A6373-A6380. [CrossRef]

113. Chihara, K.; Katogi, A.; Kubota, K.; Komaba, S. $\mathrm{KVPO}_{4} \mathrm{~F}$ and $\mathrm{KVOPO}_{4}$ toward 4 volt-class potassium-ion batteries. Chem. Commun. 2017, 53, 5208-5211. [CrossRef]

114. Kim, H.; Seo, D.-H.; Bianchini, M.; Clément, R.J.; Kim, H.; Kim, J.C.; Tian, Y.; Shi, T.; Yoon, W.-S.; Ceder, C. A new strategy for high-voltage cathodes for K-ion batteries: Stoichiometric $\mathrm{KVPO}_{4} \mathrm{~F}$. Adv. Energy Mater. 2018, 8, 1801591. [CrossRef]

115. Fedotov, S.S.; Luchinin, N.D.; Aksyonov, D.A.; Morozov, A.V.; Ryazantsev, S.V.; Gaboardi, M.; Plaisier, J.R.; Stevenson, K.J.; Abakumov, A.M.; Antipov, E.V. Titanium-based potassium-ion battery positive electrode with extraordinarily high redox potential. Nat. Commun. 2020, 11, 1484. [CrossRef] [PubMed]

116. Headden, W.P. A phosphate near triphylite from the Black Hills. Amer. J. Sci. 1891, 41, 416-417.

117. Krutik, V.M.; Puscharovskii, D.Y.; Pobedimskaya, E.A.; Belov, N.V. Crystal structure of arrojadite. Soy. Phys.-Crystallogr. 1979, 24, 425-429.

118. Moore, P.B.; Araki, T.; Merlino, S.; Mellini, M.; Zanazzi, P.F. The arrojadite-dickinson series, $\mathrm{KNa}_{4} \mathrm{Ca}(\mathrm{Fe}, \mathrm{Mn})^{2+}{ }_{14} \mathrm{Al}(\mathrm{OH})_{2}\left(\mathrm{PO}_{4}\right)_{12}$ : Crystal structure and crystal chemistry. Am. Mineral. 1981, 66, 1034-1049.

119. Kallfaß, C.; Hoch, C.; Schier, H.; Simon, A.; Schubert, H. The transition metal-rich orthophosphate arrojadite with special structural features. Z. Naturforsch. B 2010, 65, 1427-1433. [CrossRef]

120. Yakubovich, O.V.; Matvienko, E.N.; Simonov, M.A.; Mel'nikov, O.K. Crystal structure of synthetic $\mathrm{Fe}^{3+}$-arrojadite with ideal formula of $\mathrm{K}_{2} \mathrm{Na}_{5} \mathrm{Fe}^{2+}{ }_{14} \mathrm{Fe}^{3+}\left[\mathrm{PO}_{4}\right]_{12}(\mathrm{OH})_{2}$. Mosc. Univ. Geol. Bull. 1986, $41,35-47$.

121. Hoch, C. Vom Mineral lernen. Nachr. Chem. 2012, 60, 1181-1184. [CrossRef]

122. Fedotov, S.S.; Aksyonov, D.A.; Samarin, A.S.; Karakulina, O.M.; Hadermann, J.; Stevenson, K.J.; Khasanova, N.R.; Abakumov, A.M.; Antipov, E.V. Tuning the Crystal Structure of $A_{2} \mathrm{CoPO}_{4} \mathrm{~F}(A=\mathrm{Li}$, $\mathrm{Na}$ ) Fluoride-Phosphates: A New Layered Polymorph of $\mathrm{LiNaCoPO}_{4}$ F. Eur. J. Inorg. Chem. 2019, 4365-4372. [CrossRef]

123. Yakubovich, O.V.; Mass, W.; Kireev, V.V.; Urusov, V.S. Cation distribution in the crystal structure of $\mathrm{Li}_{2.32} \mathrm{Fe}_{0.56}{ }^{3+}\left[\mathrm{PO}_{4}\right] \mathrm{F}-\mathrm{a}$ synthetic structural analog of grandidierite. Dokl. Phys. 2006, 51, 474-480. [CrossRef]

124. Yakubovich, O.V.; Belokoneva, E.L.; Tsirelson, V.G.; Urusov, V.S. Electron density distribution in synthetic triphylite $\mathrm{LiFePO}_{4}$. Mosc. Univ. Geol. Bull. 1990, 45, 93-99.

125. Yakubovich, O.V.; Belokoneva, E.L.; Tsirelson, V.G.; Urusov, V.S. Electron density distribution and chemical bond in maricite $\mathrm{NaFePO}_{4}$. Mosc. Univ. Geol. Bull. 1992, 47, 46-56.

126. Yakubovich, O.V.; Belokoneva, E.L.; Tsirelson, V.G.; Urusov, V.S. Distribution pattern of electronic density in Fe-sarcopside crystals $\mathrm{Fe}_{3}\left(\mathrm{PO}_{4}\right)_{2}$. Mosc. Univ. Geol. Bull. 1991, 46, 77-84.

127. Delacourt, C.; Rodríguez-Carvajal, J.; Schmitt, B.; Tarascon, J.-M.; Masquelier, C. Crystal chemistry of the olivine-type $\mathrm{Li}_{x} \mathrm{FePO}_{4}$ system $(0 \leq \mathrm{x} \leq 1)$ between 25 and $370{ }^{\circ} \mathrm{C}$. Solid State Sci. 2005, 7, 1506-1516. [CrossRef]

128. Geller, S.; Durand, J.L. Refinement of the structure of LiMnPO . Acta Cryst. 1960, 13, 325-331. [CrossRef]

129. Moring, J.; Kostiner, E. The crystal structure of $\mathrm{NaMnPO}_{4}$. J. Solid State Chem. 1986, 61, 379-383. [CrossRef] 
130. Mishima, Y.; Hojo, T.; Nishio, T.; Sadamura, H.; Oyama, N.; Moriyoshi, C.; Kuroiwa, Y. MEM charge density study of olivine $\mathrm{LiMPO}_{4}$ and $\mathrm{MPO}_{4}(\mathrm{M}=\mathrm{Mn}, \mathrm{Fe})$ as cathode materials for lithium-ion batteries. J. Phys. Chem. C 2013, 117, 2608-2615. [CrossRef]

131. Matvienko, E.N.; Iakubovich, O.V.; Simonov, M.A.; Belov, N.V. Crystal structure of K, $\mathrm{Fe}^{3+}$-orthophosphate, $\mathrm{KFe}\left[\mathrm{PO}_{4}\right]$ F. Dokl. Akad. Nauk SSSR 1979, 246, 875-878.

(c) (C) 2020 by the authors. Licensee MDPI, Basel, Switzerland. This article is an open access article distributed under the terms and conditions of the Creative Commons Attribution (CC BY) license (http://creativecommons.org/licenses/by/4.0/). 